\title{
Targeting 24 bp within Telomere Repeat Sequences with Tandem Tetramer Pyrrole-Imidazole Polyamide Probes
}

\section{$\operatorname{AUTHOR}(S)$ :}

Kawamoto, Yusuke; Sasaki, Asuka; Chandran, Anandhakumar; Hashiya, Kaori; Ide, Satoru; Bando, Toshikazu; Maeshima, Kazuhiro; Sugiyama, Hiroshi

\section{CITATION:}

Kawamoto, Yusuke ... [et al]. Targeting 24 bp within Telomere Repeat Sequences with Tandem Tetramer Pyrrole-Imidazole Polyamide Probes. Journal of the American Chemical Society 2016, 138(42): 14100-14107

\section{ISSUE DATE:}

2016-10-26

URL:

http://hdl.handle.net/2433/230915

\section{RIGHT:}

(c) 2016 American Chemical Society. This document is the Accepted Manuscript version of a Published Work that appeared in final form in Journal of the American Chemical Society, copyright (c) American Chemical Society after peer review and technical editing by the publisher. To access the final edited and published work see https://doi.org/10.1021/jacs.6b09023. The full-text file will be made open to the public on 26 October 2017 in accordance with publisher's 'Terms and Conditions for Self-Archiving'. This is not the published version. Please cite only the published version.この論文は出版社版でありません。引用の際には出版社版をご確認ご利用ください。 


\title{
Targeting 24 bp within Telomere Repeat Sequences with Tandem Tetramer Pyrrole-Imidazole Polyamide Probes
}

\author{
Yusuke Kawamoto $^{\dagger}$, Asuka Sasaki $^{\ddagger}$, Anandhakumar Chandran $^{\dagger}$, Kaori Hashiya $^{\dagger}$ Satoru Ide ${ }^{\ddagger}$, \\ Toshikazu Bando*, ${ }^{*}$, Kazuhiro Maeshima* ${ }^{*}$, and Hiroshi Sugiyama ${ }^{*}+, \S$ \\ ${ }^{\dagger}$ Department of Chemistry, Graduate School of Science, Kyoto University, Sakyo, Kyoto 606-8502, Japan.
}

‡Biological Macromolecules Laboratory, Structural Biology Center, National Institute of Genetics, and Department of Genetics, School of Life Science, Graduate University for Advanced Studies (Sokendai), Mishima, Shizuoka 4118540, Japan.

§Institute for Integrated Cell-Material Science (WPI-iCeMS), Kyoto University, Sakyo, Kyoto 6o6-8501, Japan.

\begin{abstract}
Synthetic molecules that bind sequence-specifically to DNA have been developed for varied biological applications, including anticancer activity, regulation of gene expression, and visualization of specific genomic regions. Increasing the number of base pairs targeted by synthetic molecules strengthens their sequence specificity. Our group has been working on the development of pyrrole-imidazole polyamides that bind to the minor groove of DNA in a sequence-specific manner without causing denaturation. Recently, we reported a simple synthetic method of fluorescent tandem dimer polyamide probes composed of two hairpin moieties with a linking hinge, which bound to $12 \mathrm{bp}$ in human telomeric repeats $\left(5^{\prime}-(\text { TTAGGG })_{n}-3^{\prime}\right)$ and could be used to specifically visualize telomeres in chemically fixed cells under mild conditions. We also performed structural optimization and extension of the target base pairs to allow more specific staining of telomeres. In the present study, we synthesized tandem tetramer polyamides composed of four hairpin moieties, targeting 24 bp in telomeric repeats, the longest reported binding site for synthetic, non-nucleic-acid-based, sequence-specific DNAbinding molecules. The novel tandem tetramers bound with a nanomolar dissociation constant to 24 bp sequences made up of four telomeric repeats. Fluorescently labeled tandem tetramer polyamide probes could visualize human telomeres in chemically fixed cells with lower background signals than polyamide probes reported previously, suggesting that they had higher specificity for telomeres. Furthermore, high-throughput sequencing of human genomic DNA pulled down by the biotin-labeled tandem tetramer polyamide probe confirmed its effective binding to telomeric repeats in the complex chromatinized genome.
\end{abstract}

\section{Introduction}

Sequence-specific DNA binding molecules have potential as DNA-based therapeutics and diagnostics. Various kinds of programmable, sequence-specific DNA-binding molecules have been developed, including the clustered regularly interspaced short palindromic repeats (CRISPR)/CRISPR-associated caspase 9 (Cas9) systems, ${ }^{1}$ protein-based zinc fingers, ${ }^{2}$ transcription activator-like effector (TALE), ${ }^{3}$ and nucleic-acid-based triplex-forming oligonucleotides (TFO). ${ }^{4}$ Chemically modified nucleic acid analogues such as peptide nucleic acids (PNA) can also function as TFOs. ${ }^{5}$ Other synthetic, non-nucleic-acidbased sequence-specific DNA-binding molecules have been reported, including amidine-benzimidazole-phenyl (ABP)-based minor groove binders, ${ }^{6}$ DNA-binding fragments of transcription factors, ${ }^{7}$ threading polyintercalators $^{8}$ and minor groove-binding pyrrole-imidazole (PyIm) polyamides. ${ }^{9}$ Our group has been working on pyrroleimidazole $(\mathrm{Py}-\mathrm{Im})$ polyamides first described by Dervan and coworkers. Py-Im polyamides are composed of $\mathrm{N}$ methylpyrrole, $\mathrm{N}$-methylimidazole, and aliphatic amino acids connected by amide bonds, and they bind sequencespecifically to the minor groove of double-stranded B-DNA by recognizing Watson-Crick base pairs. The binding rule is that antiparallel arrangement of $\mathrm{Im} / \mathrm{Py}$ can bind to $\mathrm{G} \cdot \mathrm{C}$ base pairs, whereas $\mathrm{Py} / \mathrm{Py}$ can bind to both $\mathrm{A} \cdot \mathrm{T}$ and $\mathrm{T} \cdot \mathrm{A}$ base pairs. ff,g $^{\mathrm{f}}$ Referred to as aliphatic amino acid residues, the C-terminal $\beta$-alanine tail and $\gamma$-aminobutyric acid or 2,4-diaminobutyric acid (Dab) turn moiety, called a $\gamma$-turn, also binds to $\mathrm{A} \cdot \mathrm{T}$ and $\mathrm{T} \cdot \mathrm{A}$ base pairs. ${ }^{10}$ The $\gamma$-turn connects two aromatic peptides to form hairpin ${ }^{11}$ and cyclic $^{12}$ structures, and the $\mathrm{C}$-terminal $\beta$-alanine tail increases sequence specificity and binding affinity. ${ }^{13 \mathrm{a}}$ In contrast, internal $\beta$-alanine can form $\beta / \beta, \beta /$ Py and $\beta / \mathrm{Im}$ pairs as a substitution for Py rings and can relax the curvature of the polyamides to allow their efficient binding. ${ }^{1{ }^{b} \mathrm{~b}} \mathrm{Py}$-Im polyamides can be synthesized easily by machine-assisted solid-phase peptide 


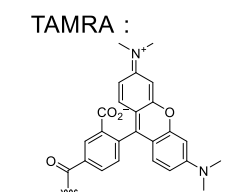

Biotin :
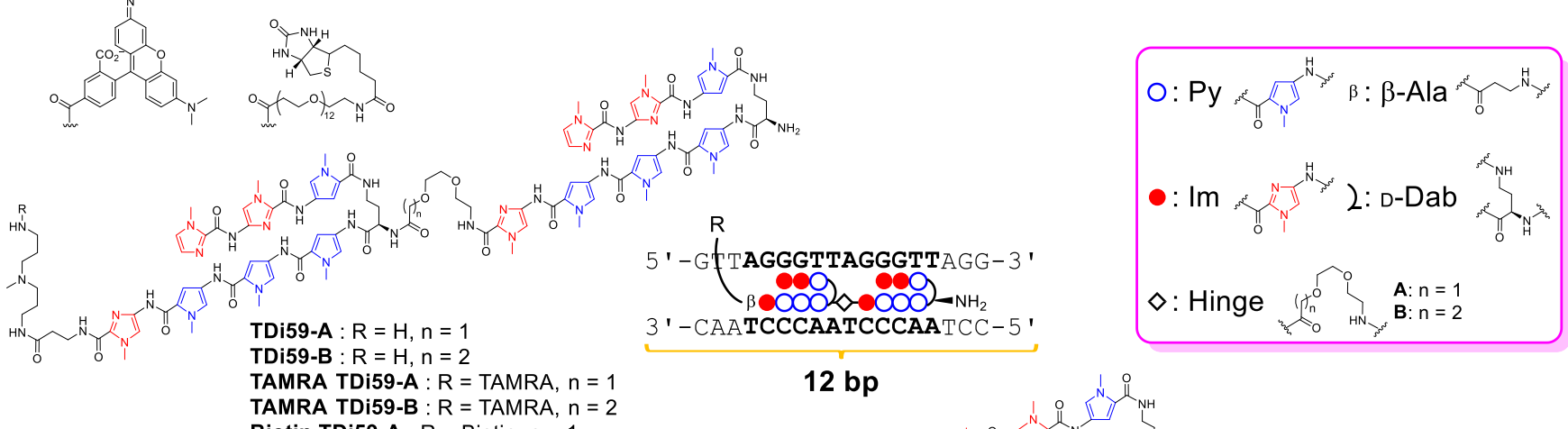

TAMRA TDi59-B : $\mathrm{R}=$ TAMRA, $\mathrm{n}=2$

$12 \mathrm{bp}$

Biotin TDi59-A : $\mathrm{R}=$ Biotin, $\mathrm{n}=1$
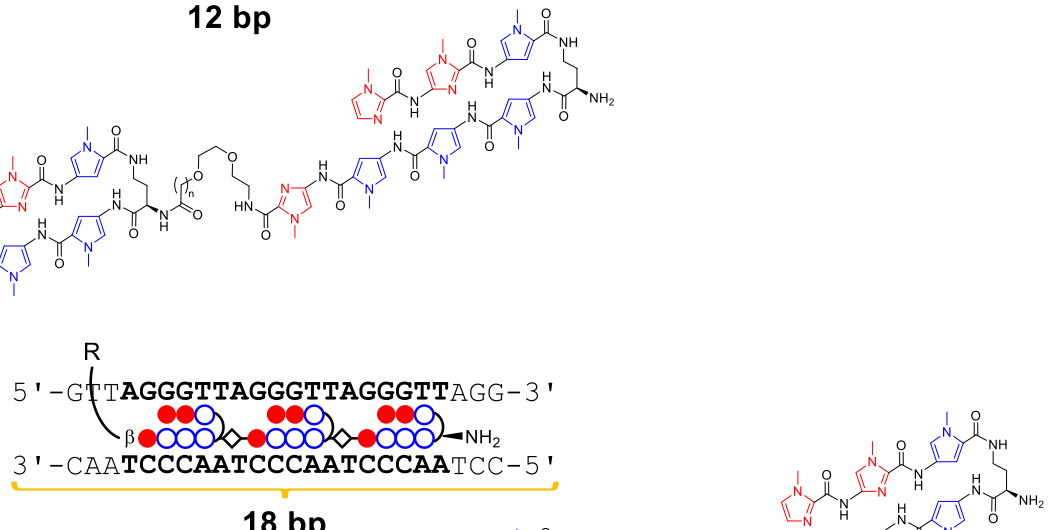

TTri59-A : $\mathrm{R}=\mathrm{H}, \mathrm{n}=1$

$18 \mathrm{bp}$
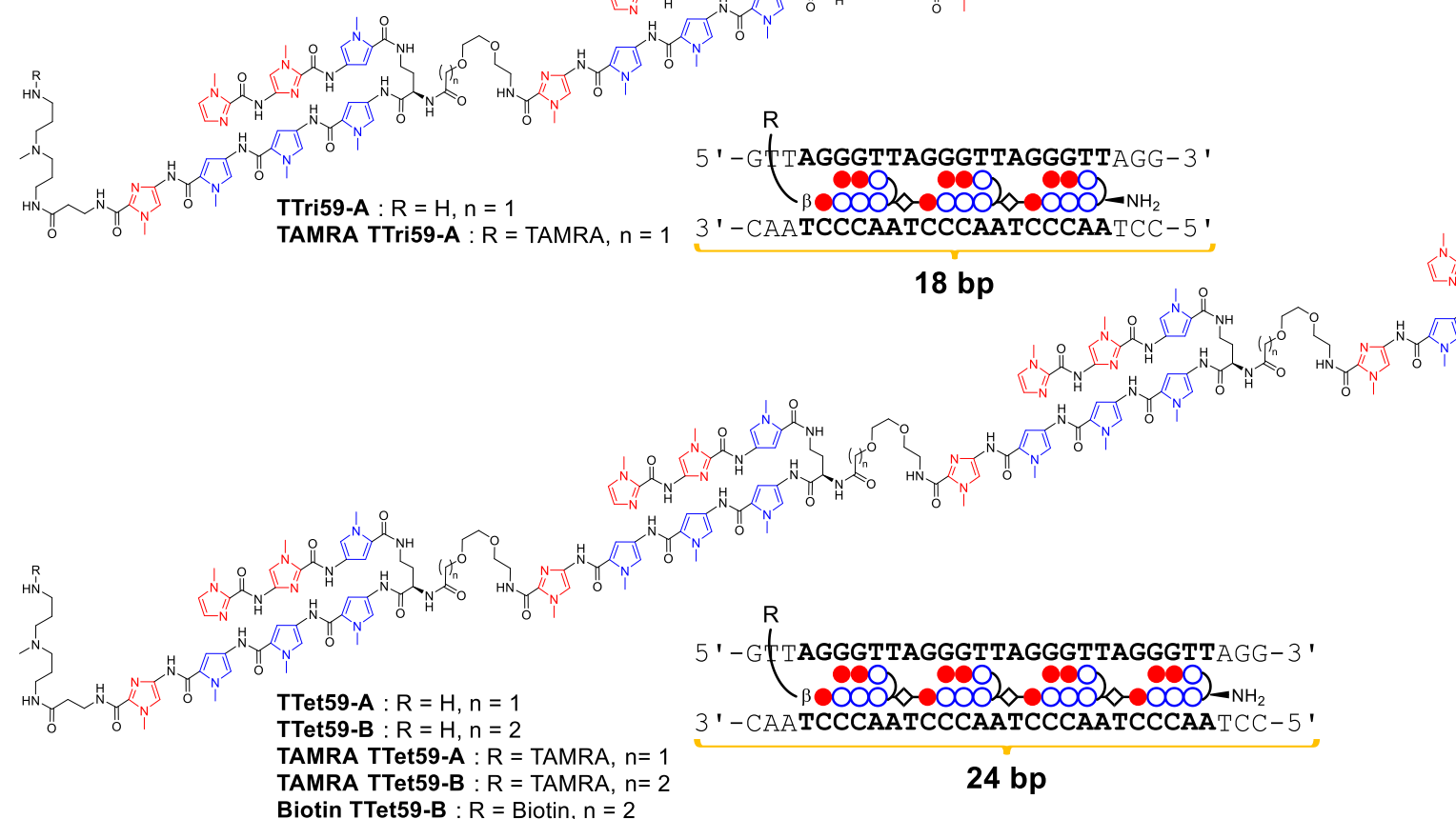

Figure 1. Chemical structures and schematic representations of tandem dimer TDi59-A and -B, TAMRA TDi59-A and -B and Biotin TDi59-A, tandem trimer TTri59-A and TAMRA TTri59-A, and tandem tetramer TTet59-A and B and TAMRA TTet59-A and -B and Biotin TTet59-B targeting for $12 \mathrm{bp}, 18 \mathrm{bp}$, and $24 \mathrm{bp}$ in human telomere sequence, respectively.

synthesis (SPPS) ${ }^{12 d, 14}$ and have been used for many purposes; for example, visualization of specific sequences, ${ }^{15}$ pull-down and identification of binding regions, ${ }^{16}$ inhibition of gene expression, ${ }^{17}$ transcriptional activation, ${ }^{18,19}$ and detection of specific sequences on a solid substrate. ${ }^{20}$ To target a single site in the whole human genome, which comprises about 3 billion base pairs, a sequence of $\geq 16 \mathrm{bp}$ must be recognized by DNA-binding molecules; therefore, many efforts have been made to extend the target base-pair sequence of such DNA ligands. Wilson and coworkers succeeded in selectively targeting a 1o bp sequence with ABP motifs. ${ }^{6 a}$ Mascareñas and coworkers have recently synthesized a DNA-binding peptide targeting $13 \mathrm{bp}$, which is composed of the DNA-binding fragments of two transcription factors connected by a hook. ${ }^{7}$ Iverson and coworkers have developed threading polyintercalators, composed of naphthalene diimide intercalators and minor groove and major groove binding aliphatic linkers, which target $14 \mathrm{bp}$ and 22 bp. ${ }^{8}$ This 22 bp sequence was at that time the longest site recognized by a synthetic, non-nucleic-acid-based DNA binding molecule. Regarding Py-Im polyamides, a linear Py-Im polyamide monomer forming a homodimer with two molecules, and a cysteine-derived Py-Im polyamide dimer were both reported to bind to 16 bp sequences. ${ }^{21}$ Furthermore, tandem hairpin motifs composed of several hairpin moieties with connecting hinge segments have also been demonstrated. ${ }^{22,23}$

Recently, our group has designed tandem hairpin Py-Im polyamides specific for the human telomere repetitive sequences $5^{\prime}$-(TTAGGG) $)_{n}-3^{\prime} .23$ The human telomere is composed of tandem repeats of $5^{\prime}$-TTAGGG $-3^{\prime}$ and the protein 
complex called shelterin including TRF1, TRF2, Rap1, TIN2, TPP1 and POT1. The telomere protects the ends of the chromosomes from nucleolytic degradation and DNA recombination and thus is important in chromosome stability. ${ }^{24}$ Human telomere DNA has a duplex region and a single-stranded $3^{\prime}$ overhang, which is suggested to form Gquadruplexes or t-loops. ${ }^{25}$ In normal mammalian cells, the number of telomere repeats decreases with cell division and is related to the aging process and cancer. ${ }^{24 a, c, f}$ Therefore, the telomere length is an important biomarker in studies of these processes, and many techniques to visualize telomeres and to measure telomere length have been reported. ${ }^{15 \mathrm{~b}}$ Fluorescence in situ hybridization (FISH) using fluorescent PNA probes has been widely used, but this method normally denatures the DNA under the harsh conditions required for efficient probe binding to telomeres and can lead to destruction of telomere structures. ${ }^{26}$ In contrast, Py-Im polyamides can bind to target sequences under mild conditions and thus can visualize target regions without destroying their structures. ${ }^{23 e}$ Based on a previous report of visualization of telomeres and estimation of their length in chemically fixed cells with Texas Red-labeled PyIm polyamide probes, ${ }^{23 a}$ our group developed a simple method for synthesis of Py-Im polyamide probes labeled with 5-carboxytetramethylrhodamine (TAMRA) that bound to $12 \mathrm{bp}$ of the human telomere sequences. The probes were named tandem dimer TDi59-A and TAMRA TDi59-A (Figure 1) and were synthesized from a fluorenylmethyloxycarbonyl (Fmoc) building block comprising the sequence from (R)-Dab to the $\mathrm{N}$-terminus of a hairpin moiety. ${ }^{23 b-d}$ Costaining with the fluorescent Py-Im polyamide probe and anti-TRF 1 antibody under mild conditions confirmed that fluorescently labeled TDi59-A could specifically visualize human telomeres in chemically fixed cells and that telomere length is related to the amount of shelterin. ${ }^{32 a, b}$ To decrease the background signals from nonspecific binding in telomere staining, we also developed TAMRA TDi59-B, containing hinge $B$ lengthened by one methylene unit, ${ }^{23 \mathrm{C}}$ and tandem trimer TAMRA TTri59-A, whose target sequence was extended to $18 \mathrm{bp}$, the longest specific sequence reported for Py-Im polyamides. ${ }^{23 \mathrm{~d}}$ Furthermore the $\mathrm{Py}$-Im polyamide probes can also visualize telomeres in tissue sections. ${ }^{23}$

In this study, we have synthesized, using an automatic solid-phase peptide synthesizer, novel tandem tetramer Py-Im polyamides TTet59-A and -B (Figure 1) targeting 24

\section{Scheme 1. Solid-phase Synthesis of Tandem Tetramer Py-Im Polyamides and the Structure of Building Block} 1.
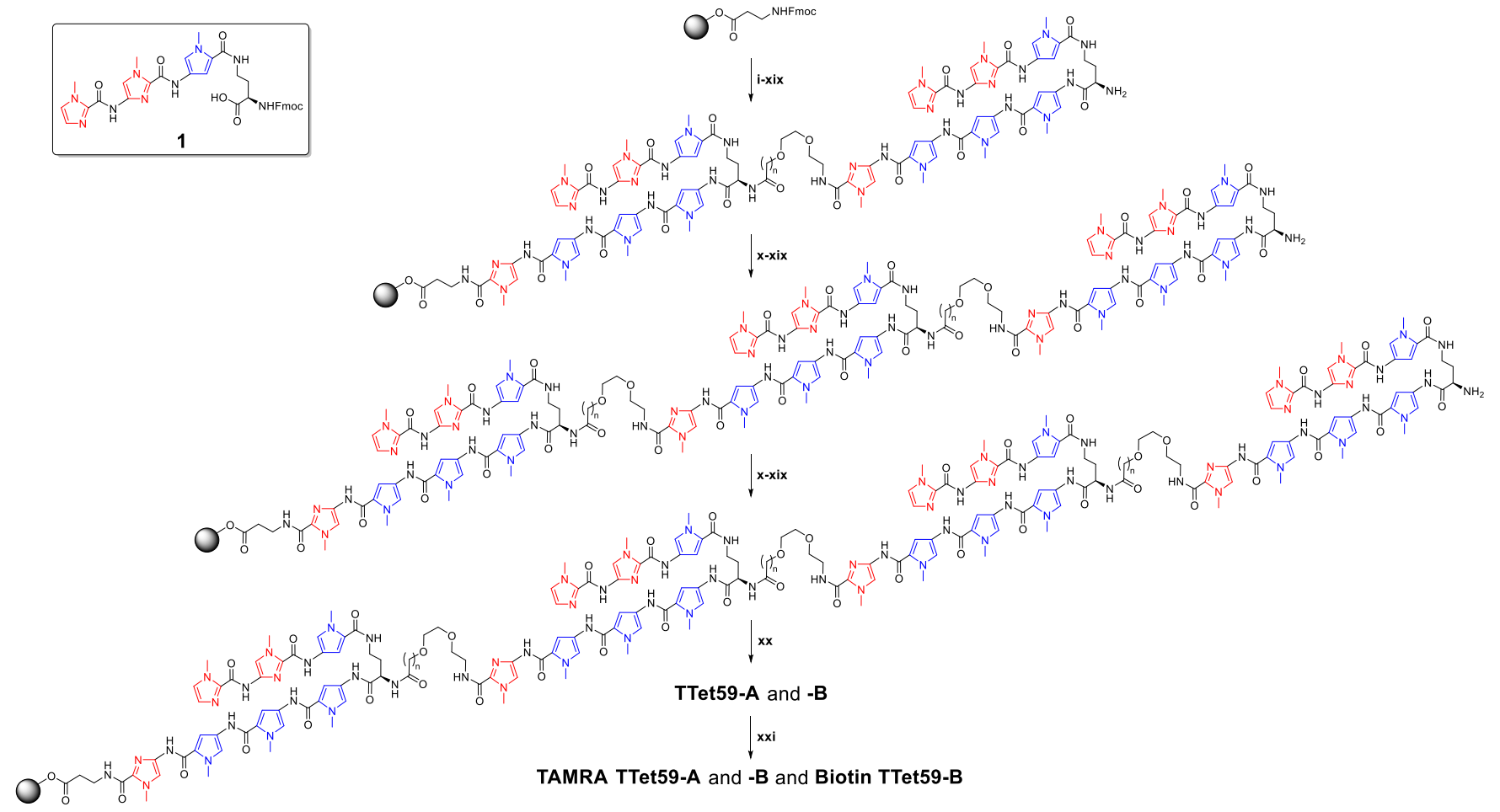

Reagents and conditions: (i) $20 \%$ piperidine, DMF; (ii) Fmoc-PyIm- $\mathrm{CO}_{2} \mathrm{H}$, HCTU, DIEA, NMP; (iii) $20 \%$ piperidine, DMF; (iv) Fmoc-Py- $\mathrm{CO}_{2} \mathrm{H}$, HCTU, DIEA, NMP; (v) 20\% piperidine, DMF; (vi) Fmoc-Py- $\mathrm{CO}_{2} \mathrm{H}$, HCTU, DIEA, NMP; (vii) $20 \%$ piperidine, DMF; (viii) 1, HCTU, DIEA, NMP; (ix) $20 \%$ piperidine, DMF; (x) Fmoc-mini-PEG or N-Fmoc-Amido-dPEG 2 Acid, HCTU, DIEA, NMP; (xi) 20\% piperidine, DMF; (xii) Fmoc-PyIm-CO ${ }_{2} \mathrm{H}, \mathrm{HCTU}$, DIEA, NMP; (xiii) $20 \%$ piperidine, DMF; (xiv) Fmoc-Py-CO ${ }_{2} \mathrm{H}, \mathrm{HCTU}$, DIEA, NMP; (xv) 20\% piperidine, DMF; (xvi) Fmoc-Py-CO $\mathrm{CH}_{2} \mathrm{HCTU}$, DIEA, NMP; (xvii) 20\% piperidine, DMF; (xviii) 1, HCTU, DIEA, NMP; (xix) 20\% piperidine, DMF; (xx) 3,3'-diamino- $N$ methyldipropylamine, $45^{\circ} \mathrm{C}$; (xxi) 5-carboxytetramethylrhodamine succinimidyl ester or EZ-Link NHS-PEG 5 $_{12}$-Biotin, DIEA, DMF. 
bp in the human telomere $5^{\prime}-(\text { TTAGGG })_{n}-3^{\prime}$ repeats. These Py-Im polyamides are composed of four hairpin units and three hinges, either A or B. To our knowledge, 24 bp is the new record for the longest binding site of synthetic, nonnucleic-acid-based, sequence-specific DNA-binding molecules. Surface plasmon resonance (SPR) analysis was performed to assess the binding affinity to four telomere repeats of the two tandem tetramer Py-Im polyamides and tandem trimer TTri59-A. After conjugation of TTet59-A and -B with TAMRA to obtain TAMRA TTet59-A and -B, we stained telomeres in chemically fixed cells to compare the new Py-Im polyamide probes with those previously reported and found that the background signals derived from nonspecific binding were much lower for the tetramers than for previously reported Py-Im polyamide probes. Finally, TDi59-A and TTet59-B were conjugated to biotin, allowing us to assess their binding to telomeric repeats in the whole genome using high-throughput sequencing technology. ${ }^{16 f, g, 27}$

\section{Results and Discussion}

Synthesis of Py-Im Polyamides. As shown in Scheme 1, tandem tetramer Py-Im polyamides TTet59-A and -B were synthesized based on the reported methodology, using building block 1 corresponding to Dab and three-ring Py and Im beside the N-terminal. ${ }^{23 \mathrm{~b}-\mathrm{d}}$ In detail, machineassisted Fmoc solid-phase peptide synthesis (SPPS) from Fmoc- $\beta$-Ala-Wang resin was performed. Fmoc-protected resin was treated with $20 \%$ piperidine $/ N, N$-dimethylformamide (DMF) for deprotection, followed by coupling with the next Fmoc block (Fmoc-Py-OH, Fmoc-PyIm$\mathrm{OH},{ }^{28} \quad \mathbf{1}^{23 \mathrm{~b}-\mathrm{d}}$ Fmoc-mini-PEG or $\mathrm{N}$-Fmoc-amido-dPEG2 Acid) activated with $N, N$-diisopropylethylamine (DIEA) and $N, N, N, N$-tetramethyl-O-(6-chloro-1H-benzotriazol-1yl) uronium hexafluorophosphate (HCTU) in $N$-methyl-2pyrrolidone (NMP). After these two procedures were repeated 19 times, the N-terminal Fmoc-protected amino group was deprotected with $20 \%$ piperidine and then cleaved from the resin with 3,3'-diamino- $N$-methyldipropylamine at $45{ }^{\circ} \mathrm{C}$ to produce TTet59-A and -B with $2.7 \%$ and $7.7 \%$ yield, respectively. The resulting Py-Im polyamides were coupled with 5-carboxytetramethylrhodamine or biotin succinimidyl ester in DIEA and DMF to produce the fluorescent probes TAMRA TTet59-A and -B and the biotinylated Py-Im polyamides Biotin TDi59-A and Biotin TTet59-B. Analytical high-performance liquid chromatography (HPLC) profiles and electrospray ionization time-of-

Table 1. Binding Affinities of Polyamides TTet59A, TTet59-B and TTri59-A against Match Sequence (ODN-1) Calculated with SPR.

\begin{tabular}{|c|c|c|c|}
\hline & $k_{\mathrm{a}}\left(\mathrm{M}^{-1} \mathrm{~s}^{-1}\right)$ & $k_{\mathrm{d}}\left(\mathrm{s}^{-1}\right)$ & $K_{\mathrm{D}}(\mathrm{M})$ \\
\hline 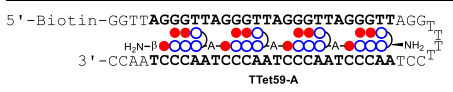 & $5.7 \times 10^{4}$ & $4.3 \times 10^{-4}$ & $7.5 \times 10^{-9}$ \\
\hline 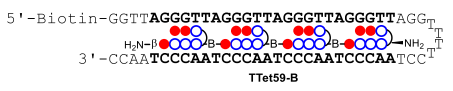 & $4.1 \times 10^{4}$ & $1.6 \times 10^{-4}$ & $4.0 \times 10^{-9}$ \\
\hline 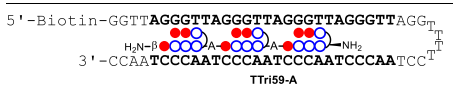 & $7.9 \times 10^{4}$ & $4.8 \times 10^{-4}$ & $6.1 \times 10^{-9}$ \\
\hline
\end{tabular}

flight mass (ESI-TOF-MS) spectrometry spectra are shown in Figures $S_{1}$ and $S_{2}$, respectively.

Comparative Analysis of Binding to Match Sequence. Binding affinities of tetramers TTet59-A and -B and tandem trimer TTri59-A to telomere repeats were assessed with SPR. ${ }^{23 c, d, 29} \quad 5^{\prime}$-Biotinylated ODN-1 (5'-biotinGGTTAGGGTTAGGGTTAGGGTTAGGGTTAGGTTTTCCT AACССТАACССТАAСССТАACССТАACC-3') containing four telomeric repeats was immobilized to a sensor chip through a biotin-streptavidin interaction, and then the trimer and tetramers were passed over the DNA on the sensor

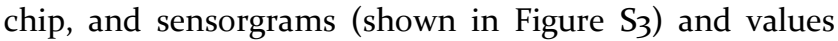
(summarized in Table 1) were obtained. The underlined bases are the binding site of these three types of Py-Im polyamides. Tetramer TTet59-A showed strong binding affinity to ODN-1 $\left(K_{\mathrm{D}}=7.5 \mathrm{nM}\right)$, comparable to other types of PyIm polyamides. ${ }^{9}$ Trimer TTri59-A showed a slightly higher association constant and stronger binding affinity than TTet59-A $\left(K_{\mathrm{D}}=6.1 \mathrm{nM}\right)$. As suggested previously, ${ }^{23 \mathrm{~d}}$ a major reason for this result is that the tetramer's higher steric hindrance influenced its accessibility to the match site. Of the three Py-Im polyamides, TTet59-B showed the strongest binding affinity $\left(K_{\mathrm{D}}=4.0 \mathrm{nM}\right)$, attributed to a much slower dissociation, suggesting that the hinge region prevented the polyamide's dissociation.

Visualization of Human Telomeres to Compare PyIm Polyamide Probes. To compare the abilities of Py-Im polyamide probes to stain telomeres specifically, we doubly stained human HeLa 1.3 cell spreads with 4',6-diamidino-2-phenylindole (DAPI) and five Py-Im polyamide probes: TAMRA TDi59-A and -B, TAMRA TTri59-A, and TAMRA TTet59-A and -B. ${ }^{23}$ Cell spreads are used for clinical karyotyping tests and are prepared from colcemidtreated mitotic cells fixed with $\mathrm{MeOH} / \mathrm{AcOH}$. The resulting images of chromosomes stained with $75 \mathrm{nM}$ Py-Im polyamide probes are shown in Figures 2 and $\mathrm{S}_{4} \mathrm{~A}$. Chromosomal regions and nuclei were visualized with DAPI. Each Py-Im polyamide probe showed two foci at the ends of every chromosome, suggesting that all probes, including the new tandem tetramer probes TAMRA TTet59-A and B, could stain telomeres specifically. As the number of targeted base pairs increased, the fluorescence of the polyamide probes became lower, presumably because increasing the size of the polyamide probes decreased the number of molecules binding to telomeres, but the background signals derived from nonspecific binding of polyamides decreased. When treating cells with TAMRA TDi59-A or -B or TAMRA TTri59-A, we could easily observe the shape of chromosomes from the background signals of polyamides, and stronger background signals for TAMRA TDi59-A in particular were detected from the whole chromosomes. However, for treatment with TAMRA TTet59-A or -B, the intensity of background signals was less, showing that extending the target base pair sequence significantly improves telomere specificity in cells. In addition, TAMRA TTet59-B had less background signal along the chromosomes than TAMRA TTet59-A, suggesting that the change 
A

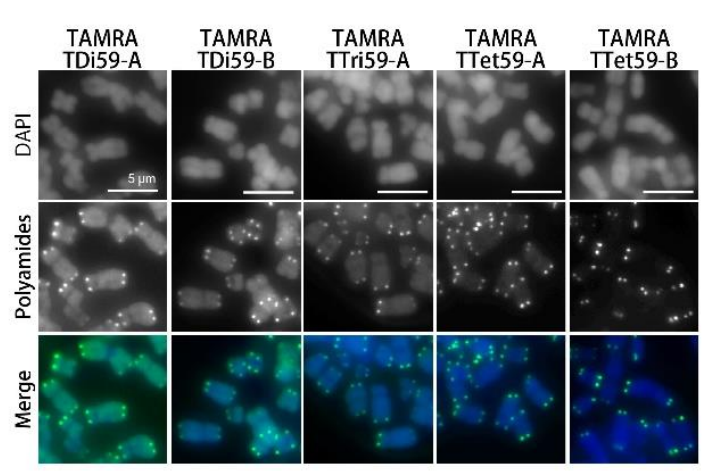

B

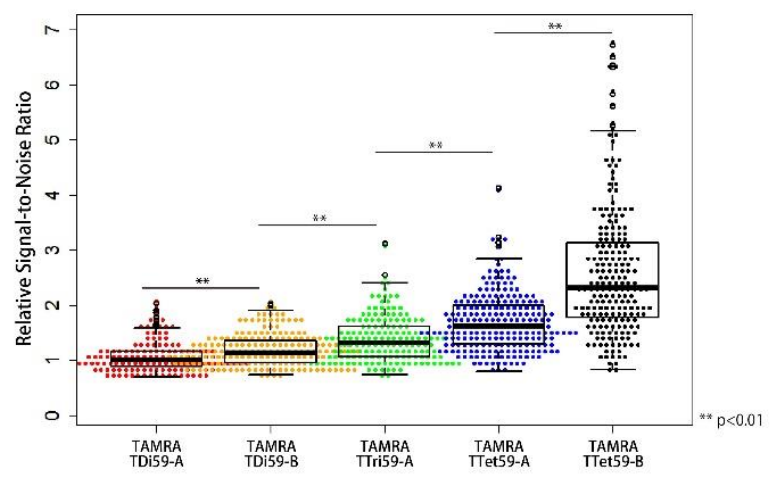

Figure 2. Telomere staining of HeLa 1.3 cell spreads with $75 \mathrm{nM}$ fluorescent Py-Im polyamide probes. (A) The images of HeLa 1.3 cell spreads stained with DAPI (first row) and the fluorescent polyamide probes (second row). The merged images are shown in the third row. Original images are shown in Figure $\mathrm{S}_{4} \mathrm{~A}$. (B) Distribution of relative signal-to-noise $(\mathrm{S} / \mathrm{N})$ ratio of telomeric foci in the images.

of hinge from A to B is also effective in improving specificity; this was also shown by the comparison between TAMRA TDi59-A and -B. ${ }^{23 \mathrm{C}}$ As shown in Figure $2 \mathrm{~B}$, TAMRA TTet59-B had the highest relative signal-to-noise $(\mathrm{S} / \mathrm{N})$ ratio. These results demonstrated that increasing the number of target base pairs to 24 and changing the hinge from A to B suppressed the nonspecific binding and allowed us to observe telomeres in HeLa 1.3 cell spreads with high specificity.

Images of telomere staining of HeLa 1.3 cells fixed in formaldehyde (Figures 3 and $\mathrm{S}_{4} \mathrm{~B}$ ), a commonly used fixation method in cell biology, and the quantitative analysis of $\mathrm{S} / \mathrm{N}$ ratios (Figure $3 \mathrm{~B}$ ) suggested that the results were consistent with those of cell spreads staining. Many sharp foci from the telomeric regions were observed in the nuclei of cells. ${ }^{23 a, b}$ As reported previously, TAMRA TDi59-B and TAMRA TTri59-A showed lower background signals than TAMRA TDi59-A. ${ }^{23 c, d}$ The background signals of the two tandem tetramer probes TAMRA TTet59-A and -B were lower and their $\mathrm{S} / \mathrm{N}$ ratios were higher than the other three probes. As can be seen from the polyamide signals of TAMRA TTet59-A and -B shown in Figure 3, the shapes of the whole nuclei were less distinct. In the images of formaldehyde-fixed cells, TAMRA TTet59-B also showed the
A

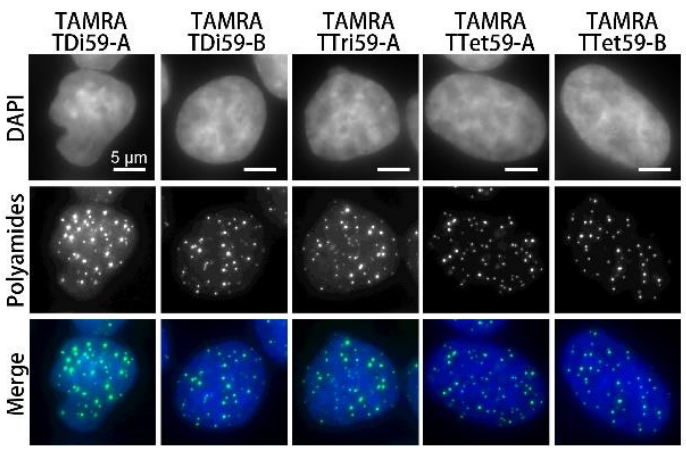

B

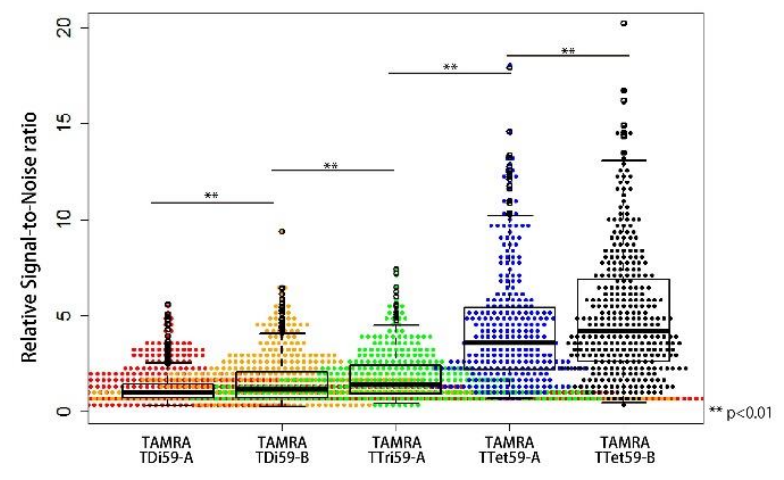

Figure 3. Telomere staining of HeLa 1.3 cells with 15 nM fluorescent Py-Im polyamide probes. (A) The images of HeLa 1.3 cells stained with DAPI (first row) and fluorescent polyamide probes (second row). The merged images are shown in the third row. Original images are shown in Figure $\mathrm{S}_{4} \mathrm{~B}$. (B) Distribution of signal-to-noise $(\mathrm{S} / \mathrm{N})$ ratio of telomeric foci in the images.

highest $\mathrm{S} / \mathrm{N}$ ratio. These results also demonstrated that TAMRA TTet59-A and -B could visualize telomeres with higher specificity in the fixed cells or formaldehyde-fixed cells and that TAMRA TTet59-B targeting $24 \mathrm{bp}$ and composed of four hairpins and three B hinges had the highest telomere specificity of the fluorescent Py-Im polyamidebased telomere probes.

High-throughput Sequencing of the Binding Sites of Py-Im Polyamide Probes for Telomeric Repeats. Images of chromosome spreads treated with the Py-Im polyamide probes (Figure 2) suggested that they specifically stained telomeres. To assess their efficient binding to telomeric repeats in a biologically active, histone-packed, chromatinized genome, we performed high-throughput sequencing of DNA bound to Biotin TDi59-A and Biotin TTet59-B, based on the reported procedure. ${ }^{16 f, g}$ The workflow is shown in Scheme 2. In brief, nuclei were extracted from BJ fibroblast cells and then incubated with $400 \mathrm{nM}$ Biotin TDi59-A or Biotin TTet59-B for $16 \mathrm{~h}$ at $4{ }^{\circ} \mathrm{C}$. After this, the extracted nuclei were treated with micrococcal nuclease to produce mononucleosomes to generate the optimally sized DNA for construction of a sequencing library. Nuclear proteins were digested with proteinase K, and then DNA bound to the biotinylated Py-Im polyamide 
Scheme 2. Extraction and High-throughput Sequencing of Genomic DNA Bound by Biotinylated Py-Im Polyamide Probes.

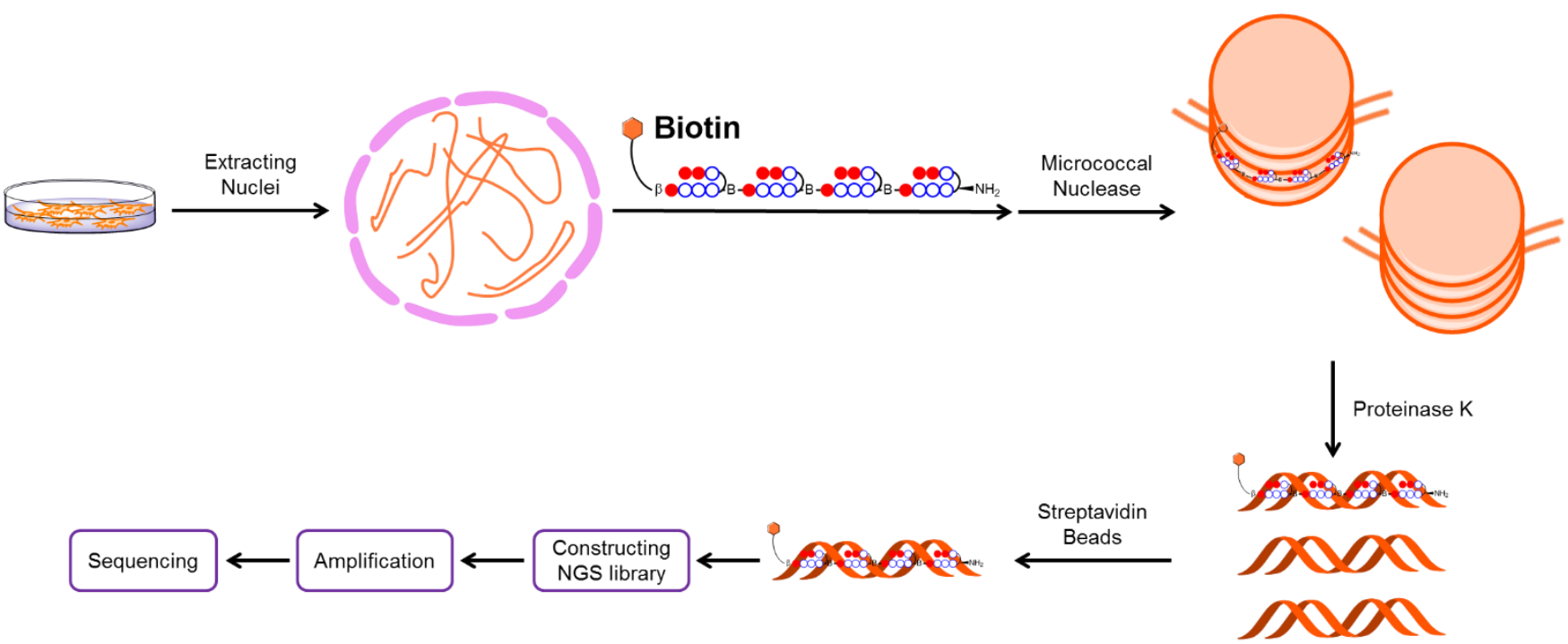

probes was extracted through a biotin-streptavidin interaction on streptavidin-coated magnetic beads ( $\mathrm{C}_{1}$ beads). The extracted and purified DNA was ligated with sequencing platform-specific adapters and amplified with a polymerase chain reaction to obtain sufficient amounts for a sequencing library. The qualified libraries were sequenced using Ion Proton Sequencing system. Sequenced and filtered reads were aligned to human reference genome $\mathrm{hg}_{3} 8$. MACS peaks were called to identify the differentially enriched regions compared with control data. ${ }^{30 a}$

Figure $\mathrm{S}_{5}$ shows a representative result indicating the enriched regions in chromosomes 1 and 18 , and a close-up of the enriched telomeric repeats from a non-treated control sample and after Biotin TDi59-A and Biotin TTet59-B treatment is shown in Figure 4. In both left and right arm termini of chromosomes 1 and 18, we observed significant enrichments with both polyamides compared with the control. The enrichment was consistent with telomeric repeat sequences (TTAGGG/CCCTAA) of the reference genome, suggesting that we could successfully validate the binding of Biotin TDi59-A and Biotin TTet59-B to telomeric repeats with high-throughput sequencing. Other mild enrichments appeared to be the results of partial or non-specific binding.

The enrichments in the termini of each chromosome are shown in Figure S6. Duplicate experiments ensured the consistency of enrichments in chromosomal termini. However, we could not quantify the enrichment level on $\mathrm{Chr}{ }_{3} \mathrm{R}$, ${ }_{5} \mathrm{R}, 6 \mathrm{~L}, 6 \mathrm{R}, 8 \mathrm{~L}, 8 \mathrm{R},{ }_{9} \mathrm{R}, 11 \mathrm{~L}, 13 \mathrm{~L}, 14 \mathrm{~L}, 14 \mathrm{R},{ }_{15} \mathrm{~L}, 16 \mathrm{R}, 17 \mathrm{~L}, 19 \mathrm{~L}$, 20L, 20R, $21 \mathrm{~L}$ and $22 \mathrm{~L}$ (L- left arm, R- right arm) chromosomal termini. This may be because of lacking telomeric repeat sequences information on the above mentioned chromosomes in the human reference genome hg38 data. Even though chromosomes 13, 14, 15, 21 and 22 lack the telomeric repeats information at the left termini presumably because of rDNA whose sequences are not included in the human reference genome $\mathrm{hg}_{3} 8$, we could observe enrichments from $\sim 16000000 \mathrm{bp}, \sim 16000000 \mathrm{bp}, \sim 17000000 \mathrm{bp}$, $\sim 5010000 \mathrm{bp}$ and $\sim 10510000 \mathrm{bp}$, respectively. These results show that Biotin TDi59-A and Biotin TTet59-B could effectively recognize and bind to telomeric repeats.

To identify high affinity binding motif of Biotin TDi59A and Biotin TTet59-B from the enrichments, we used the Homer motif analysis program with the enriched peaks. ${ }^{30 b}$ One of the highly enriched motifs corresponded to telomeric $5^{\prime}-(\text { TTAGGG })_{n}-3^{\prime}$ repeats with a $p$ value of $\mathrm{e}^{-8595}$ and $\mathrm{e}^{-100}$ for Biotin TDi59-A and Biotin TTet59-B, respectively. (Figure ${ }_{4} \mathrm{~B}$ ). This result also suggests efficient binding of Biotin TDi59-A and Biotin TTet59-B to telomeres.

Finally, to compare the recognition of telomeric repeats by Biotin TDi59-A with that by Biotin TTet59-B, the ratio of reads containing $\geq 4$ TTAGGG/CCCTAA repeats to whole sequenced reads was calculated. As shown in Figure ${ }_{4} \mathrm{C}$, the ratio for Biotin TDi59-A was 18.2 times higher than the nontreated control, showing that Biotin TDi59-A could enrich telomeric DNA. The ratio for Biotin TTet59B was 1.9 times higher than that for Biotin TDi59-A, suggesting that TTet59-B exhibited better recognition ability toward telomeric repeats. This result is also consistent with the higher telomere-specific staining of TAMRA TTet59-B.

High-throughput sequencing confirmed the binding of Biotin TDi59-A and Biotin TTet59-B to telomeric repeats in the whole genome. In contrast, foci of fluorescently labeled Py-Im polyamide probes were specifically detected at the end of the chromosomes (Figure 2). The principal reason for this is that accumulation of the Py-Im polyamides on long telomeric repeats in telomere regions was higher than that in nonspecific regions, and therefore much stronger fluorescence was detected at the termini of chromosomes than from other chromosomal regions.

\section{Conclusion}

In this study, we have synthesized novel tandem tetramer Py-Im polyamides composed of 4 hairpins and 3 hinges that targeted $24 \mathrm{bp}$ of the human telomere sequences. This is a new record for the longest binding site of synthetic, non-nucleic-acid-based, sequence-specific 
DNA-binding molecules. SPR analysis revealed that tandem tetramers could bind to four telomeric repeats with nanomolar $K_{\mathrm{D}}$ values. TAMRA-labeled tandem tetramer Py-Im polyamide probes could stain clearly the telomere foci in chemically fixed cells. Compared with previously reported tandem dimer and trimer Py-Im polyamides, the tandem tetramers had higher specificity for telomeres in cells, and TAMRA TTet59-B containing hinge B had the highest specificity. Furthermore, high-throughput sequencing of chromatin pulled down by biotin-labeled $\mathrm{Py}-$ Im polyamide probes confirmed their high recognition and binding toward telomeric DNA. To the best of our knowledge, this is the first report of high-throughput sequencing of DNA pulled down by a synthetic DNA binder targeting human telomeres. To allow the application of these tetramers, our group continues to optimize further their chemical structures and to develop new functions.

\section{A}
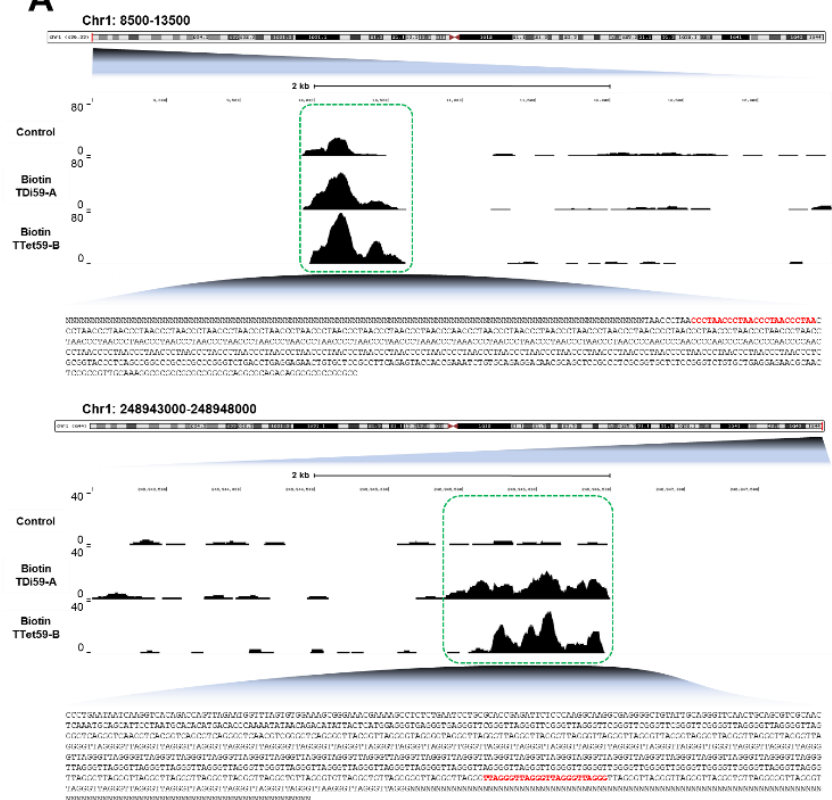

\section{ASSOCIATED CONTENT}

Supporting Information. Materials and Methods, Mass spectra and HPLC profiles of tandem tetramers, SPR sensorgrams, Cell images, Some enrichment data obtained from high throughput sequencing. This information is available free of charge via the internet at http://pubs.acs.org.

\section{AUTHOR INFORMATION}

\section{Corresponding Author}

(H.S.) hs@kuchem.kyoto-u.ac.jp

(K. M.) kmaeshim@nig.ac.jp

(T. B.) bando@kuchem.kyoto-u.ac.jp

\section{Notes}

The authors declare no competing financial interests.

\section{ACKNOWLEDGMENT}

We thank Dr T. de Lange (Rockefeller University) for the gift of HeLa 1.3 cells, Dr S. Sugano (Kyoto University) for helpful discussion about high throughput sequencing, S. Asamitsu (Kyoto University) for assistance in SPR data analysis, S. Sato (Kyoto University) for culturing BJ cells. Y. K. is thankful to JSPS research fellowship for young scientists $\left(D_{1}\right)$. This work was supported by Basic Science and Platform Technology Program for Innovative Biological Medicine to H. S., JSPS-NSF International Collaborations in Chemistry (ICC) to H. S., NIG

B

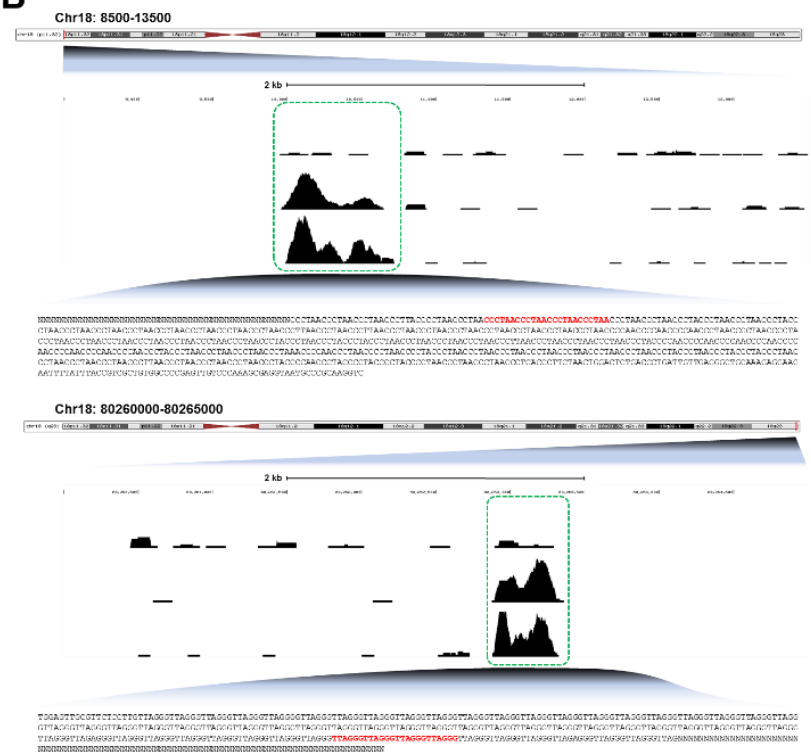

C

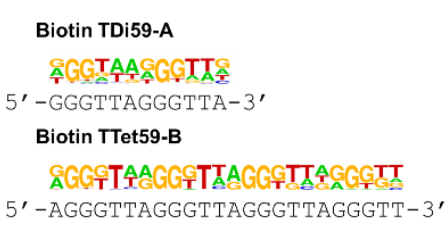

D

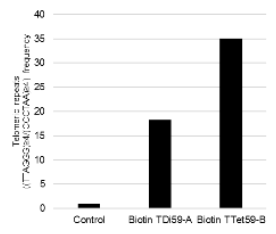

Figure 4. Assessment of efficient binding of Biotin TDi59-A and Biotin TTet59-B to telomeric repeats with highthroughput sequencing. Mapping of the biotinylated Py-Im polyamide probes binding and enriched sites in both termini of chromosomes 1 and 18 are shown in (A) and (B) respectively. (C) Binding motifs of the probes corresponding to telomeric repeats identified in human genomic enriched sequences. (D) The ratio of sequenced reads containing $\geq$ 4 telomeric repeats to whole reads as normalized to that from the control. 
Collaborative Research Program (2015-B6) to K. M. and H. S., JST-CREST to K. M. and JSPS KAKENHI Grant number 24225005 to H. S., 24310155 to T. B. and 15 Joog28 to Y. K.

\section{REFERENCES}

(1) Jinek, M.; Chylinski, K.; Fonfara, I.; Hauer, M.; Doudna, J. A.; Charpentier, E. Science 2012, 337, 816-821.

(2) Klug, A. Annu. Rev. Biochem. 2010, 79, 213-231.

(3) Boch, J.; Scholze, H.; Schornack, S.; Landgraf, A.; Hahn, S.; Kay, S.; Lahaye, T.; Nickstadt, A.; Bonas, U. Science 2009, 326, 1509-1512.

(4) (a) Duca, M.; Vekhoff, P.; Oussedik, K.; Halby, L.; Arimondo, P. B. Nucleic Acids Res. 20o8, 36, 5123-5138. (b) Moser, H. E.; Dervan, P. B. Science 1987, 238, 645-650.

(5) (a) Nielsen, P. E. Chem. Biodivers. 2010, 7, 786-804. (b) Nielsen, P. E.; Egholm, M.; Berg, R. H.; Buchardt, O. Science 1991, 254, 1497 -1500 .

(6) (a) Liu, Y.; Chai, Y.; Kumar, A.; Tidwell, R. R.; Boykin, D. W.; Wilson, W. D. J. Am. Chem. Soc. 2012, 134, 5290-5299. (b) Paul, A.; Nanjunda, R.; Kumar, A.; Laughlin, S.; Nhili, R.; Depauw, S.; Deuser, S. S.; Chai, Y.; Chaudhary, A. S.; David-Cordonnier, M. H.; Boykin, D. W.; Wilson, W. D. Bioorg. Med. Chem. Lett. 2015, 25, 4927-4932.

(7) Rodríguez, J.; Mosquera, J.; García-Fandiño, R.; Vázquez, M. E.; Mascareñas, J. L. Chem. Sci. 2016, 7, 3298-3303.

(8) (a) Holman, G. G.; Zewail-Foote, M.; Smith, A. R.; Johnson, K. A.; Iverson, B. L. Nat. Chem. 2o11, 3, 875-881. (b) Smith, A. R.; Iverson, B. L. J. Am. Chem. Soc. 2013, 135, 12783-12789.

(9) (a) Dervan, P. B. Bioorg. Med. Chem. 2001, 9, 2215-2235. (b) Dervan, P. B.; Edelson, B. S. Curr. Opin. Struc. Biol. 2003, 13, 284299. (c) Dervan, P. B.; Doss, R. M.; Marques, M. A. Curr. Med. Chem.: Anti-Cancer Agents. 2005, 5, 373-387. (d) Bando, T.; Sugiyama, H. Acc. Chem. Res. 20o6, 39, 935-944. (e) Blackledge, M. S.; Melander, C. Bioorg. Med. Chem. 2013, 21, 6101-6114. (f) Trauger, J. W.; Baird, E. E.; Dervan P. B. Nature 1996, 382, 559-561. (g) White, S.; Szewczyk, J. W.; Turner, J. M.; Baird, E. E.; Dervan, P. B. Nature 1998, 391, 468-471.

(10) (a) Herman, D. M.; Baird, E. E.; Dervan, P. B. J. Am. Chem. Soc. 1998, 120, 1382-1391. (b) Swalley, S. E.; Eldon E. Baird, E. E.; Dervan, P. B. J. Am. Chem. Soc. 1999, 121, 1113-1120.

(11) (a) Mrksich, M.; Parks, M. E.; Dervan. P. B. J. Am. Chem. Soc. 1994, 116, 7983-7988. (b) de Clairac, R. P. L.; Geierstanger, B. H.; Mrksich, M.; Dervan, P. B.; Wemmer, D. E. J. Am. Chem. Soc. 1997, 119, 7909-7916.

(12) (a) Herman, D. M.; Turner, J. M.; Baird, E. E.; Dervan, P. B. J. Am. Chem. Soc. 1999, 121, 1121-1129. (b) Chenoweth, D. M.; Dervan, P. B. Proc. Natl. Acad. Sci. U. S. A. 2009, 106, 13175-13179. (c) Chenoweth, D. M.; Dervan, P. B. J. Am. Chem. Soc. 2010, 132, 1452114529. (d) Morinaga, H.; Bando, T.; Takagaki, T.; Yamamoto, H.; Hashiya, K.; Sugiyama, H. J. Am. Chem. Soc. 2011, 133, 18924-18930. (e) Li, B. C.; Montgomery, D. C.; Puckett, J. W.; Dervan, P. B. J. Org. Chem. 2013, 78, 124-133.

(13) (a) Parks, M. E.; Baird, E. E.; Dervan, P. B. J. Am. Chem. Soc. 1996, 118, 6147-6152. (b) Turner, J. M.; Swalley, S. E.; Baird, E. E.; Dervan, P. B. J. Am. Chem. Soc. 1998, 120, 6219-6226.

(14) (a) Baird, E. E.; Dervan, P. B. J. Am. Chem. Soc. 1996, 118, 61416146. (b) Wurtz, N. R.; Turner. J. M.; Baird, E. E.; Dervan, P. B. Org. Lett. 2001, 3, 1201-1203. (c) Fan, L.; Yao, G.; Pan, Z.; Wu, C.; Wang, H. S.; Burley, G. A.; Su, W. Org. Lett. 2015, 17, 158-161.
(15) (a) Vaijayanthi, T.; Bando, T.; Pandian, G. N.; Sugiyama, H. ChemBioChem 2012, 13, 2170-2185. (b) Boutorine, A. S.; Novopashina, D. S.; Krasheninina, O. A.; Nozeret, K.; Venyaminova, A. G. Molecules 2013, 18, 15357-15397. (c) Nozeret, K.; Loll, F.; Escudé, C.; Boutorine, A. S. ChemBioChem 2015, 16, 549-554.

(16) (a) Anandhakumar, C.; Kizaki, S.; Bando, T.; Pandian, G. N.; Sugiyama, H. ChemBioChem 2015, 16, 20-38. (b) Meier, J. L.; Yu, A. S.; Korf, I.; Segal, D. J.; Dervan, P. B. J. Am. Chem. Soc. 2012, 134, 17814-17822. (c) Kang, J. S.; Meier, J. L.; Dervan, P. B. J. Am. Chem. Soc. 2014, 136, 3687-3694. (d) Erwin, G. S.; Bhimsaria, D.; Eguchi, A.; Ansari, A. Z. Angew. Chem. Int. Ed. 2014, 53, 10124-10128. (e) Anandhakumar, C.; Li, Y.; Kizaki, S.; Pandian, G. N.; Hashiya, K.; Bando, T.; Sugiyama, H. ChemBioChem. 2014, 15, 2647-2651. (f) Chandran, A.; Syed, J.; Taylor, R. D.; Kashiwazaki, G.; Sato, S.; Hashiya, K.; Bando, T.; Sugiyama, H. Nucleic Acids Res. 2016, 44, 4014-4024. (g) Chandran, A.; Syed, J.; Li, Y.; Sato, S.; Bando, T.; Sugiyama, H. ChemBioChem. 2016, DOI: 10.1002/cbic.201600274.

(17) (a) Murty, M. S. R. C.; Sugiyama, H. Biol. Pharm. Bull. 2004, 27, 468-474. (b) Gottesfeld, J. M.; Neely, L.; Trauger, J. W.; Baird, E. E.; Dervan, P. B. Nature 1997, 387, 202-205. (c) Lai, Y.-M.; Fukuda, N.; Ueno, T.; Kishioka, H.; Matsuda, H.; Saito, S.; Matsumoto, K.; Ayame, H.; Bando, T.; Sugiyama, H.; Mugishima, H.; Serie, K. J. Pharmacol. Exp. Ther. 2005, 315, 571575. (d) Hiraoka, K.; Inoue, T.; Taylor, R. D.; Watanabe, T.; Koshikawa, N.; Yoda, H.; Shinohara, K.; Takatori, A.; Sugimoto, K.; Maru, Y.; Denda, T.; Fujiwara, K.; Balmain, A.; Ozaki, T.; Bando, T.; Sugiyama, H.; Nagase, H. Nat. Commun. 2015, 6, 6706.

(18) (a) Xiao, X.; Yu, P.; Lim, H. S.; Sikder, D.; Kodadek, T. Angew. Chem. Int. Ed. 2007, 46, 2865-2868. (b) Patel, S.; Jung, D.; Yin, P.; Carlton, P.; Yamamoto, M.; Bando, T.; Sugiyama, H.; Lee, K. B. ACS Nano. 2014, 8, 8959-8967.

(19) (a) Han, L.; Pandian, G. N.; Junetha, S.; Sato, S.; Chandran, A.; Taniguchi, J.; Saha, A.; Bando, T.; Nagase, H.; Sugiyama, H. Angew. Chem. Int. Ed. 2013, 52, 13410-13413. (b) Pandian, G. N.; Taniguchi, J.; Junetha, S.; Sato, S.; Han, L.; Saha, A.; Anandhkumar, C.; Bando, T.; Nagase, H.; Vaijayanthi, T.; Taylor, R. D.; Sugiyama, H. Sci. Rep. 2014, 4, 3843. (c) Han, L.; Pandian, G, N.; Chandran, A.; Sato, S.; Taniguchi, J.; Kashiwazaki, G.; Sawatani, Y.; Hashiya, K.; Bando, T.; Xu, Y.; Qian, X.; Sugiyama, H. Angew. Chem. Int. Ed. 2015, 54, $8700-8703$.

(20) Singh, I.; Wendeln, C.; Clark, A. W.; Cooper, J. M.; Ravoo, B. J.; Burley, G. A. J. Am. Chem. Soc. 2013, 135, 3449-3457.

(21) (a) Trauger, J. W.; Baird, E. E.; Dervan, P. B. J. Am. Chem. Soc. 1998, 120, 3534-3535. (b) Yamamoto, M.; Bando, T.; Morinaga, N.; Kawamoto, Y.; Hashiya, K.; Sugiyama, H. Chem. Eur. J. 2014, 20, 752-759.

(22) (a) Herman, D. M.; Baird, E. E.; Dervan, P. B. Chem. Eur. J. 1999, 5, 975-983. (b) Kers, I.; Dervan, P. B. Bioorg. Med. Chem. 2002, 10, 3339-3349. (c) Schaal, T. D.; Mallet, W. G.; McMinn, D. L.; Nguyen, N. V.; Sopko, M. M.; John, S.; Parekh, B. S. Nucleic Acids Res. 2003, 31, 1282-1291. (d) Sasaki, S.; Bando, T.; Minoshima, M.; Shinohara, K.; Sugiyama, H. Chem. Eur. J. 2oo8, 14, 864-870. (e) Yamamoto, M.; Bando, T.; Kawamoto, Y.; Taylor, R.; Hashiya, K.; Sugiyama, H. Bioconjugate Chem. 2014, 25, 552-559. (f) Taylor, R, D.; Kawamoto, Y.; Hashiya, K.; Bando, T.; Sugiyama, H. Chem. Asian J. 2014, 9, 2527-2533.

(23) (a) Maeshima, K.; Janssen, S.; Laemmli, U. K. EMBO J. 2oo1, 20, 3218-3228. (b) Kawamoto, Y.; Bando, T.; Kamada, F.; Li, Y.; Hashiya, K.; Maeshima, K.; Sugiyama, H. J. Am. Chem. Soc. 2013, 135, 16468-16477. (c) Hirata, A.; Nokihara, K.; Kawamoto, Y.; Bando, T.; Sasaki, A.; Ide, S.; Maeshima, K.; Kasama, T.; Sugiyama, H. J. Am. Chem. Soc. 2014, 136, 11546-11554. (d) Kawamoto, Y.; Sasaki, A.; Hashiya, K.; Ide, S; Bando, T.; Maeshima, K; Sugiyama. H. Chem. Sci. 2015, 6, 2307-2312. (e) Sasaki, A.; Ide, S.; 
Kawamoto, Y.; Bando, T.; Murata, Y.; Shimura, M.; Yamada, K.; Hirata, A.; Nokihara, K.; Hirata, T.; Sugiyama, H.; Maeshima, K. Sci. Rep. 2016, 6, 29261.

(24) (a) Smogorzewska, A.; de Lange, T. Annu. Rev. Biochem. 2004, 73, 177-208. (b) Palm, W.; de Lange, T. Annu. Rev. Genet. 2008, 42, 301-334. (c) Blackburn, E. H. Angew. Chem. Int. Ed. 2010, 49, 74057421. (d) Xu, Y. Chem. Soc. Rev. 2011, 40, 2719-2740. (e) Nandakumar, J.; Cech, T. R. Nat. Rev. Mol. Cell Biol. 2013, 14, 69-82. (f) Zakian, V. A. Exp. Cell Res. 2o12, 318, 1456-146o. (g) Smogorzewska, A.; van Steensel, B.; Bianchi, A.; Oelmann, S.; Schaefer, M. R.; Schnapp, G.; de Lange, T. Mol. Cell Biol. 2ooo, 2o, 1659-1668.

(25) (a) Biffi, G.; Tannahill, D.; McCafferty, J.; Balasubramanian, S. Nat. Chem. 2013, 5, 182-186. (b) Doksani, Y.; Wu, J, Y.; de Lange, T.; Zhuang, X. Cell 2o13, 155, 345-356.

(26) Lansdorp, P. M.; Verwoerd, N. P.; van de Rijke, F. M.; Dragowska, V.; Little, M. T.; Dirks, R. W.; Raap, A. K.; Tanke, H. J. Hum. Mol. Genet. 1996, 5, 685-691.
(27) Anders, L.; Guenther, M. G.; Qi, J.; Fan, Z. P.; Marineau, J. J.; Rahl, P. B.; Lovén, J.; Sigova, A. A.; Smith, W. B.; Lee, T. I.; Bradner, J. E.; Young, R. A. Nat. Biotechnol. 2014, 32, 92-96.

(28) (a) Minoshima, M.; Bando, T.; Sasaki, S.; Fujimoto, J.; Sugiyama, H. Nucleic Acids Res. 2008, 36, 2889-2894. (b) Wetzler, M.; Wemmer, D. E. Org. Lett. 2010, 12, 3488-3490.

(29) (a) Lacy, E. R.; Le, N. M.; Price, C. A.; Lee, M.; Wilson, W. D. J. Am. Chem. Soc. 2002, 124, 2153-2163. (b) Wang, S.; Aston, K.; Koeller, K. J.; Harris, G. D.; Rath, N. P.; Bashkin, J. K.; Wilson, W. D. Org. Biomol. Chem. 2014, 12, 7523-7536.

(30) (a) Feng, J.; Liu, T.; Qin, B.; Zhang, Y.; Liu, X. S. Nat. Protoc. 2012, 7, 1728-1740. (b) Heinz, S.; Benner, C.; Spann, N.; Bertolino, E.; Lin, Y. C.; Laslo, P.; Cheng, J. X.; Murre, C.; Singh, H.; Glass, C. K. Mol. Cell 2010, 38, 576-589. 
Insert Table of Contents artwork here

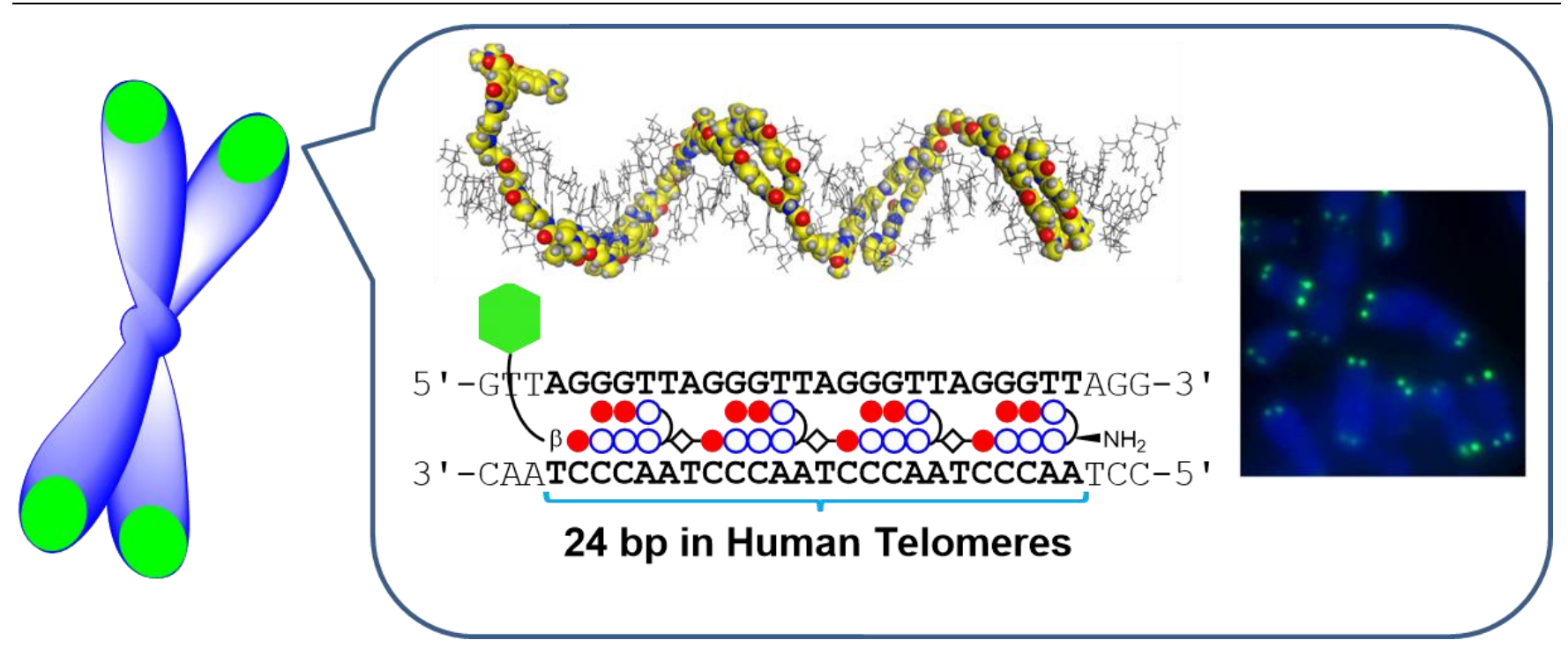




\section{Supporting Information}

\section{Targeting 24 bp in Telomere Repeat Sequences with Tandem Tetramer Pyrrole-Imidazole Polyamide Probes}

Yusuke Kawamoto ${ }^{\dagger}$, Asuka Sasaki ${ }^{\ddagger}$, Anandhakumar Chandran ${ }^{\dagger}$, Kaori Hashiya ${ }^{\dagger}$, Satoru Ide $^{\ddagger}$, Toshikazu Bando ${ }^{* \dagger}$, Kazuhiro Maeshima ${ }^{*}$, , and Hiroshi Sugiyama ${ }^{*},, \S$

†Department of Chemistry, Graduate School of Science, Kyoto University, Sakyo, Kyoto 606-8502, Japan

*Biological Macromolecules Laboratory, Structural Biology Center, National Institute of Genetics, and Department of Genetics, School of Life Science, Graduate University for Advanced Studies (Sokendai), Mishima, Shizuoka 411-8540, Japan.

${ }^{\S}$ Institute for Integrated Cell-Material Science (WPI-iCeMS), Kyoto University, Sakyo, Kyoto 606-8501, Japan.

Corresponding authors

(H. S.) hs@kuchem.kyoto-u.ac.jp

(K. M.) kmaeshim@nig.ac.jp

(T. B.) bando@kuchem.kyoto-u.ac.jp

\section{Table of Contents}

Materials and Methods S2

Figure S1. Analytical HPLC profiles of Py-Im polyamides......................................S9

Figure S2. ESI-TOF MS spectra of the Py-Im polyamides....................................... 10

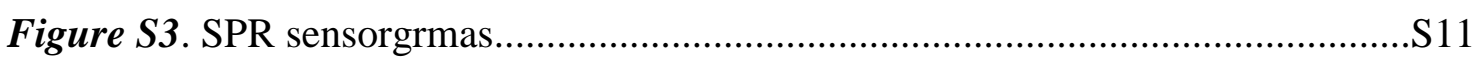

Figure S4. Telomere staining of HeLa 1.3 cells and spreads.................................S12

Figure S5. The enrichment of biotinylated Py-Im polyamide probes in the whole of chromosomes 1 and 18

Figure S6. The enrichment at both termini for all chromosomes. S14

References 


\section{Materials and Methods}

Materials. HPLC analysis for chasing each solution-phase reaction and checking each product was performed on a PU-2089 plus series system (JASCO) using CHEMCOBOND 4.6 mm x 150 mm 5-ODS-H Column (Chemco Plus Scientific Co., Ltd.) in $0.1 \%$ TFA in water with acetonitrile as the eluent at a flow rate of $1.0 \mathrm{~mL} / \mathrm{min}$ and a linear gradient elution of 0 to $50 \%$ acetonitrile in 20 min with detection at $254 \mathrm{~nm}$. Purification of Py-Im polyamides were done with reversed-phase HPLC performed on a UV2075 HPLC UV/VIS detector and a PU-2080 plus series system (JASCO) using CHEMCOBOND $4.6 \mathrm{~mm} \times 150 \mathrm{~mm}$ 5-ODS-H Column in $0.1 \%$ TFA in water with acetonitrile as the eluent at a flow rate of $1.0 \mathrm{~mL} / \mathrm{min}$. Collected fractions were lyophilized and then analyzed by ESI-TOF-MS (Bruker). For the collect mass measurement, external mass calibration (m/z: 622.0290 and 922.0098), purchased from Agilent Technologies, was used. Fmoc-mini-PEG and $N$-Fmoc-Amido-dPEG 2 Acid were purchased from Peptide International. Fmoc-Py- $\mathrm{CO}_{2} \mathrm{H}$, DMF used for solid-phase synthesis, NMP, trifluoroacetic acid (TFA), and piperidine were from Wako. HCTU was from Peptide Institute, Inc. Fmoc- $\beta$-Ala-Wang resin (0.60 mmol/g, 100-200 mesh) was from Novabiochem. DIEA was from Nacalai Tesque, Inc. DMF used for solutionphase synthesis and for telomere-staining and acetonitrile were from Kanto Chemical Co., Inc. 3, 3'-diamino- $N$-methyldipropyl-amine was from Tokyo Chemical Industry Co., Ltd. 5-carboxytetramethylrhodamine succinimidyl ester and EZ-Link NHS$\mathrm{PEG}_{12}-$ Biotin were from Thermo Fisher Scientific Inc. The Fmoc units $\mathbf{1}^{\mathrm{la}, \mathrm{b}}$ and FmocPyIm- $\mathrm{CO}_{2} \mathrm{H}^{2}$ were synthesized using the previous method. TAMRA TDi59-B was purchased from HiPep Laboratories. TAMRA TDi59-A, TTri59-A and TAMRA TTri59-A were synthesized following the previous methodology. ${ }^{1 \mathrm{~b}, \mathrm{c}}$ Solid-phase peptide synthesis was performed on a PSSM-8 (Shimadzu). Concentrations of Py-Im Polyamides were calculated with a Nanodrop ND-1000 spectrophotometer (Thermo Fisher Scientific Inc.) using an extinction coefficient of $9900 \mathrm{M}^{-1} \mathrm{~cm}^{-1}$ per one pyrrole or imidazole moiety at $\lambda_{\max }$ near $310 \mathrm{~nm}$. The SPR assays were performed using a BIACORE X instrument (GE Healthcare) with 5'-biotinylated DNA oligonucleotides (JBioS), streptavidin-coated sensor chip SA (GE Healthcare) and HBS-EP buffer (GE Healthcare). Cell images were recorded with DeltaVision (Applied Precision). HeLa 1.3 cells were generous gifts of $\mathrm{Dr} \mathrm{T}$. de Lange (Rockefeller University) and BJ fibroblast cells were purchased from ATCC. DMEM medium and streptavidin-coated magnetic beads were purchased from Invitrogen. Normal goat serum (NGS) was from Millipore. Paraphenylene diamine, Triton X-100 and protease inhibitor cocktail were from Sigma. 
DAPI was from Roche. MNase was from TaKaRa Bio Inc. Nonidet P-40 was from Nacalai Tesque, Inc. PCR purification kit was from Qiagen. Quality and quantity check of sequencing library was performed with Agilent 2100 Bioanalyzer and High sensitivity BioAnalyzer kit (Agilent Technologies). High throughput sequencing was performed with Ion Proton ${ }^{\mathrm{TM}}$ Sequencer (Thermo Fisher Scientific Inc.). All other solvents and materials were from standard suppliers (highest quality available).

General Procedures of Solid-phase Synthesis of Tandem Tetramer Py-Im Polyamides. Following the reported condition, ${ }^{1 \mathrm{c}}$ each Fmoc solid-phase peptide synthesis (SPPS) of tandem tetramers was performed with a computer-assisted operation system under low humidity $(<20 \%)$. Fmoc units in each step were as follows: Fmoc-Py-CO ${ }_{2} \mathrm{H}$ (77 mg, $\left.0.21 \mathrm{mmol}\right)$, Fmoc-PyIm-CO ${ }_{2} \mathrm{H}$ (70 mg, $\left.0.14 \mathrm{mmol}\right)$, Fmoc-DDab(ImImPy)-OH (1) (70 mg, $0.10 \mathrm{mmol})$, Fmoc-mini-PEG (81 mg, $0.21 \mathrm{mmol}$ ) and $\mathrm{N}$-Fmoc-Amido-dPEG 2 Acid (84 mg, $0.21 \mathrm{mmol}$ ). Before SPPS, each Fmoc unit was dissolved in NMP (1.0 mL) with HCTU and the amount of HCTU for Fmoc-Py-CO $\mathrm{CO}_{2} \mathrm{H}$, Fmoc-PyIm- $\mathrm{CO}_{2} \mathrm{H}, \mathbf{1}$, Fmoc-mini-PEG and $N$-Fmoc-Amido-dPEG 2 Acid was $88 \mathrm{mg}$ (0.21 mmol), $60 \mathrm{mg}(0.15 \mathrm{mmol}), 40 \mathrm{mg}(0.097 \mathrm{mmol}), 88 \mathrm{mg}(0.21 \mathrm{mmol})$ and $88 \mathrm{mg}$ $(0.21 \mathrm{mmol})$, respectively. Fmoc- $\beta$-Ala-Wang resin swelled with NMP was loaded in the reaction vessel.

Procedures were as follows: twice deblocking for 4 min with $20 \%$ piperidine/ DMF $(500 \mu \mathrm{L})$, addition of $10 \%$ DIEA/NMP (364 $\mu \mathrm{L}$, DIEA was $0.21 \mathrm{mmol})$ to Fmoc unitHCTU mixture for activation, coupling for $60 \mathrm{~min}$. Five times washing with DMF were performed during each step. After the last coupling, the deblocking of amino group at $\gamma$ turn was performed. All couplings were carried out with a single-coupling cycle. All lines were purged with solution transfers and bubbled by nitrogen gas for stirring the resin.

After SPPS, Py-Im polyamides on resin were cleaved with 3,3'-diamino- $N$ methyldipropylamine at $45{ }^{\circ} \mathrm{C}$ for $3 \mathrm{~h}$. The resin was removed by filtration and washed thoroughly with dichloromethane, and the filtrate was concentrated in vacuo. The residue was dissolved in 1.0-2.0 mL dichloromethane-methanol mixture and then more than 10-fold volume of diethyl ether was added, followed by the centrifuge and removal of the supernatant. This process was repeated a few times until white precipitation was obtained. The obtained crude products were purified by reversed-phase HPLC in $0.1 \%$ TFA in water with acetonitrile as the eluent at a flow rate of $1.0 \mathrm{~mL} / \mathrm{min}$ and a linear gradient elution of 25 to $55 \%$ acetonitrile in $40 \mathrm{~min}$. Collected fractions were lyophilized to obtain the objective compounds. 
Synthesis of TTet59-A. Solid-phase synthesis was performed with $42.0 \mathrm{mg}$ Fmoc$\beta$-Wang resin $(0.60 \mathrm{mmol} / \mathrm{g})$ and finally TTet59-A $\left(3.0 \mathrm{mg}, 6.8 \times 10^{-4} \mathrm{mmol}, 2.7 \%\right.$ yield) was obtained as a pale yellow solid. Analytical HPLC: $t_{R}=16.9 \mathrm{~min}$. ESI-TOFMS $m / z$ calcd for $\mathrm{C}_{200} \mathrm{H}_{246} \mathrm{~N}_{79} \mathrm{O}_{42}{ }^{5+}[M+5 \mathrm{H}]^{5+} 885.1903$ found 885.1820.

Synthesis of TTet59-B. Solid-phase synthesis was performed with $43.0 \mathrm{mg}$ Fmoc$\beta$-Wang resin $(0.60 \mathrm{mmol} / \mathrm{g})$ as a pale yellow solid. The resulting crude polyamide was purified as described to afford TTet59-B $\left(8.9 \mathrm{mg}, 2.0 \times 10^{-3} \mathrm{mmol}, 7.7 \%\right.$ yield $)$. Analytical HPLC: $\mathrm{t}_{\mathrm{R}}=17.1 \mathrm{~min}$. ESI-TOF-MS $m / z$ calcd for $\mathrm{C}_{203} \mathrm{H}_{252} \mathrm{~N}_{79} \mathrm{O}_{42}{ }^{5+}[M+$ $5 \mathrm{H}]^{5+} 893.5997$ found 893.5936 .

Synthesis of TAMRA TTet59-A. TTet59-A (0.9 mg) and 5-carboxytetramethylrhodamine succinimidyl ester $(0.2 \mathrm{mg})$ were dissolved in DMF $(250 \mu \mathrm{L})$ and DIEA $(0.40 \mu \mathrm{L})$, followed by mixing at room temperature with shielding the light. After checking this reaction had been finished, the reaction mixture was purified by reversedphase HPLC in $0.1 \%$ TFA in water with acetonitrile as the eluent at a flow rate of 1.0 $\mathrm{mL} / \mathrm{min}$ and a linear gradient elution of 30 to $70 \%$ acetonitrile in $30 \mathrm{~min}$, followed by lyophilization of the collected fractions to afford TAMRA TTet59-A (1.1 mg) as a purple powder. Analytical HPLC: $\mathrm{t}_{\mathrm{R}}=18.2 \mathrm{~min}$. ESI-TOF-MS $\mathrm{m} / \mathrm{z}$ calcd for $\mathrm{C}_{225} \mathrm{H}_{267} \mathrm{~N}_{81} \mathrm{O}_{46}{ }^{6+}[M+6 \mathrm{H}]^{6+} 806.5169$ found 806.5205.

Synthesis of TAMRA TTet59-B. TTet59-B $(2.6 \mathrm{mg})$ and 5-carboxytetramethylrhodamine succinimidyl ester $(0.9 \mathrm{mg})$ were dissolved in DMF $(272 \mu \mathrm{L})$ and DIEA $(0.60 \mu \mathrm{L})$. The reaction and purification were performed as described above to afford TAMRA TTet59-B $(2.0 \mathrm{mg})$ as a purple powder. Analytical HPLC: $t_{\mathrm{R}}=18.3 \mathrm{~min}$. ESI-TOF-MS $m / z$ calcd for $\mathrm{C}_{228} \mathrm{H}_{274} \mathrm{~N}_{81} \mathrm{O}_{46}{ }^{7+}[M+7 \mathrm{H}]^{7+} 697.4508$ found 697.4565 .

Synthesis of Biotin TDi59-A. TDi59-A (1.9 mg) and EZ-Link NHS-PEG ${ }_{12}$-Biotin $0.9 \mathrm{mg}$ were dissolved in DMF $(159 \mu \mathrm{L})$ and DIEA $(0.30 \mu \mathrm{L})$. The reaction and purification were performed as described above to afford Biotin TDi59-A (0.4 mg) as a white solid. Analytical HPLC: $\mathrm{t}_{\mathrm{R}}=17.4 \mathrm{~min}$. ESI-TOF-MS $\mathrm{m} / \mathrm{z}$ calcd for $\mathrm{C}_{139} \mathrm{H}_{198} \mathrm{~N}_{44} \mathrm{O}_{35} \mathrm{~S}^{4+}[M+4 \mathrm{H}]^{4+} 768.8691$ found 768.8644 .

Synthesis of Biotin TTet59-B. TTet59-B $(0.8 \mathrm{mg})$ and EZ-Link NHS-PEG ${ }_{12}-$ Biotin $0.1 \mathrm{mg}$ were dissolved in DMF $(101 \mu \mathrm{L})$ and DIEA $(0.20 \mu \mathrm{L})$. The reaction and purification were performed as described above to afford Biotin TTet59-B $(0.5 \mathrm{mg})$ as 
a white solid. Analytical HPLC: $\mathrm{t}_{\mathrm{R}}=19.0 \mathrm{~min}$. ESI-TOF-MS $\mathrm{m} / z$, calcd for $\mathrm{C}_{240} \mathrm{H}_{321} \mathrm{~N}_{82} \mathrm{O}_{57} \mathrm{~S}^{7+}[M+7 \mathrm{H}]^{7+} 756.4918$ found 756.4987 .

SPR Assays. The SPR assays were performed as described in previous reports. ${ }^{1 b, c}$ Biotinylated DNA was immobilized to streptavidin-coated sensor chip at a flow rate of $10 \mu \mathrm{L} / \mathrm{min}$ to obtain the desired immobilization level (up to approximately $1000 \mathrm{RU}$ rise). The assays were performed with HBS-EP (10 mM HEPES pH 7.4, $150 \mathrm{mM} \mathrm{NaCl}$, $3 \mathrm{mM}$ EDTA, $0.005 \%$ v/v Surfactant P20) containing $0.1 \%$ DMSO at $25{ }^{\circ} \mathrm{C}$. A series of sample solutions with various concentrations were prepared in HBS-EP buffer containing $0.1 \%$ DMSO and injected at a flow rate of $20 \mu \mathrm{L} / \mathrm{min}$. To calculate association rates $\left(k_{\mathrm{a}}\right)$, dissociation rates $\left(k_{\mathrm{d}}\right)$, and dissociation constants $\left(K_{\mathrm{D}}\right)$, data processing was performed with 1:1 binding with mass transfer model using BIAevaluation 4.1 program.

\section{Telomeres Staining and Calculation of S/N Ratios}

HeLa 1.3 Cell Spreads Treated with Fluorescent Py-Im polyamide Probes. ${ }^{1,3}$

HeLa 1.3 cells were maintained in DMEM medium containing $10 \%$ fetal bovine serum (FBS) at $37{ }^{\circ} \mathrm{C}\left(5 \% \mathrm{CO}_{2}\right)$. HeLa 1.3 cells were blocked mitotically by adding $0.2 \mu \mathrm{g} / \mathrm{mL}$ colcemid and incubated overnight. The cells were then swollen by treatment with hypotonic buffer $(0.075 \mathrm{M} \mathrm{KCl})$ for $15 \mathrm{~min}$ at room temperature, fixed with methanol/acetic acid (3:1) solution for $5 \mathrm{~min}$. After centrifugation, cell pellet was again suspended in the methanol/acetic acid (3:1) solution. The cell suspension was spread on coverslips and air-dried at room temperature for $5 \mathrm{~min}$ and then at $60{ }^{\circ} \mathrm{C}$ for $30 \mathrm{~min}$. The cell spread coverslips were kept at $4{ }^{\circ} \mathrm{C}$ until use.

The dried spread coverslips were soaked in HEN buffer (10 mM HEPES pH 7.5, 1 mM EDTA and $100 \mathrm{mM} \mathrm{NaCl}$ ) over night at $4{ }^{\circ} \mathrm{C}$ before use. For blocking, the spread coverslips were treated with $10 \%$ NGS in TE buffer $1(10 \mathrm{mM}$ Tris-HCl pH 7.5, $1 \mathrm{mM}$ EDTA) for $30 \mathrm{~min}$ at room temperature. After brief washing with TE buffer 1, the spread coverslips were incubated with 10\% NGS, $75 \mathrm{nM}$ fluorescent Py-Im polyamide probe and $0.5 \mu \mathrm{g} / \mathrm{ml}$ DAPI in TE buffer 1 containing $10 \% \mathrm{DMF}$ for $1 \mathrm{~h}$ at $37{ }^{\circ} \mathrm{C}$. After washing with TEN100 (10 mM Tris- $\mathrm{HCl}$ pH 7.5, 1 mM EDTA and $100 \mathrm{mM} \mathrm{NaCl})$ buffer (five times for $3 \mathrm{~min}$ ), the spread coverslips were mounted in PPDI solution (10 mM HEPES pH 7.5, $100 \mathrm{mM} \mathrm{KCl,} 1 \mathrm{mM} \mathrm{MgCl} 2,80 \%$ glycerol, $1 \mathrm{mg} / \mathrm{mL}$ paraphenylene diamine) and the coverslips were sealed with a nailporish. Sectioning images were recorded with DeltaVision and projected ("Quick Projection" tool) without deconvolution to obtain telomeric signals and background signals. For quantification of the telomere signals in Figure 2, the telomere signals yielded by the polyamides were 
extracted based on threshold values using the Softworks software (Applied Precision). The maximum intensity values of signals in the extracted telomere regions were then used as telomere signals. For the background signals, ROIs which were same shape of each telomere were set next to the defined each telomere signals in the chromosomes, and maximum values of the signals were used as background signals. Box plot and dot plot were created in R software.

\section{Formaldehyde-fixed HeLa 1.3 Cells Treated with Fluorescent Py-Im Polyamide} Probes. ${ }^{1}$ For polyamide staining, the HeLa 1.3 cells were grown on coverslips coated with polylysine. The cell coverslips were washed in phosphate-buffered saline (PBS) twice and fixed with $1.85 \%$ formaldehyde in PBS for $15 \mathrm{~min}$ at room temperature. The fixed cell coverslips were then treated with $50 \mathrm{mM}$ glycine in PBS for $5 \mathrm{~min}$, and permeabilized with $0.5 \%$ Triton $\mathrm{X}-100$ in PBS for $5 \mathrm{~min}$. After briefly washing with HMK buffer (10 mM HEPES pH 7.5, $\left.1 \mathrm{mM} \mathrm{MgCl}_{2}, 100 \mathrm{mM} \mathrm{KCl}\right)$ twice, the coverslips were soaked in HEN buffer for overnight and kept at $4{ }^{\circ} \mathrm{C}$ until use. For blocking, the cell coverslips were treated with $10 \%$ NGS in TE buffer 1 for 30 min at room temperature. After brief washing with TE buffer 1, the cell coverslips were incubated with $10 \%$ NGS, $15 \mathrm{nM}$ fluorescent Py-Im polyamide probe and $0.5 \mu \mathrm{g} / \mathrm{ml}$ DAPI in TE buffer 1 containing 10\% DMF for $1 \mathrm{~h}$ at $37^{\circ} \mathrm{C}$. After washing with TEN200 buffer (10 $\mathrm{mM}$ Tris- $\mathrm{HCl} \mathrm{pH} 7.5,1 \mathrm{mM}$ EDTA, and $200 \mathrm{mM} \mathrm{NaCl}$ ) (five times for $3 \mathrm{~min}$ ), the mounting and subsequent image acquisitions were performed as described above. For quantification of the telomere signals in Figure 3, they were extracted from the images as described previously. ${ }^{1}$ The telomere signals yielded by the polyamides were extracted based on threshold values using the Softworks software (Applied Precision). The maximum intensity values of signals in the extracted telomere regions were then used as telomere signals. For the background signals, 10 squares (10 pixels x 10 pixels) were randomly set outside the defined telomere signals and mean values of the signals in the squares were used as background signals. Box plot and dot plot were created in $\mathrm{R}$ software.

\section{Identification of TDi59-A and TTet59-B Binding Sites in Genome} Pull-down and Affinity Purification of DNA bound by Biotin TDi59-A and Biotin TTet59-B. ${ }^{4}$ Human foreskin BJ fibroblast cells were maintained in $8 \mathrm{~mL}$ DMEM medium containing $10 \%$ FBS, 1x non-essential amino acids, penicillin (100 units $/ \mathrm{mL})$ and streptomycin $(100 \mu \mathrm{g} / \mathrm{mL})$ at $37^{\circ} \mathrm{C}\left(5 \% \mathrm{CO}_{2}\right) .75-80 \%$ confluent cells $\left(2 \times 10^{6}\right.$ cells) were washed with PBS and isolated by tripsinization for 3 min. 3 plates of $2 \times 10^{6}$ 
cells were used. Each isolated $2 \times 10^{6}$ cells were again washed with cold PBS and the cell pellet was suspended in $5 \mathrm{~mL}$ ice cold NP-40 lysis buffer (10 mM Tris- $\mathrm{HCl} \mathrm{pH} 7.4$, $10 \mathrm{mM} \mathrm{NaCl}, 3 \mathrm{mM} \mathrm{MgCl} 2,0.5 \%$ Nonidet $\mathrm{P}-40,0.15 \mathrm{mM}$ spermine, $0.5 \mathrm{mM}$ spermidine and $0.015 \mathrm{x}$ protease inhibitor cocktail) and incubated on ice for $5 \mathrm{~min}$. The nuclei were pelleted by centrifugation at $300 \mathrm{~g}$ for $10 \mathrm{~min}$ and then carefully dissolved in $900 \mu \mathrm{L}$ binding buffer (10 mM Tris- $\mathrm{HCl} \mathrm{pH} 8.0,5 \mathrm{mM} \mathrm{MgCl} 2,1 \mathrm{mM}$ Dithiothreitol, $0.3 \mathrm{M} \mathrm{KCl}, 0.3 \mathrm{x}$ protease inhibitor cocktail and $10 \%$ glycerol $)^{4 \mathrm{~b}}$ and incubated at $4{ }^{\circ} \mathrm{C}$ for $1 \mathrm{~h}$. $100 \mu \mathrm{L}$ of the binding buffer containing $1 \mu \mathrm{L}$ of $400 \mu \mathrm{M}$ biotinylated Py-Im polyamide probe dissolved in DMSO was added to the extracted nuclei solution. Each 2 x $10^{6}$ cells nuclei were incubated with biotinylated Py-Im polyamide probe $(400 \mathrm{nM}$ final concentration) dissolved in DMSO $\left(0.1 \%\right.$ final concentration) at $4{ }^{\circ} \mathrm{C}$ for $16 \mathrm{~h}$. After incubation, the nuclei were pelleted by centrifugation at $5200 \mathrm{rpm}$ for $10 \mathrm{~min}$ and then washed with $1 \mathrm{~mL}$ washing buffer A (10 mM Tris- $\mathrm{HCl} \mathrm{pH} 7.4,15 \mathrm{mM} \mathrm{NaCl}, 60$ $\mathrm{mM} \mathrm{KCl}, 0.15 \mathrm{mM}$ spermine, $0.5 \mathrm{mM}$ spermidine and $0.1 \mathrm{x}$ protease inhibitor cocktail). After removal of washing buffer A by centrifuge at $5200 \mathrm{rpm}$ for $10 \mathrm{~min}$, the pellets were resuspended in $50 \mu \mathrm{L}$ MNase buffer (20 mM Tris- $\mathrm{HCl}$ pH 8.0, $5 \mathrm{mM} \mathrm{NaCl}, 2.5$ $\mathrm{mM} \mathrm{CaCl}_{2}$ ). Then 4 units micrococcal nuclease (MNase) in $50 \mu \mathrm{L}$ MNase buffer containing $43 \mu \mathrm{g}$ RNase A and $0.2 x$ protease inhibitor cocktail was added to the solution, followed by incubation at $37{ }^{\circ} \mathrm{C}$ for 30 min to digest to mononucleus. ${ }^{4 b}$ After this digestion $2 \mu \mathrm{L}$ of $0.5 \mathrm{M}$ EDTA was added to quench MNase and then histone protein was removed by addition of $4 \mu \mathrm{L}$ of $20 \mathrm{mg} / \mathrm{mL}$ proteinase $\mathrm{K}$ solution and incubation at $37{ }^{\circ} \mathrm{C}$ for $30 \mathrm{~min}$. After MNase digestion and proteinase $\mathrm{K}$ treatment, the suspension was mixed with equal volume of modified COSMIC ${ }^{4 a}$ buffer $(20 \mathrm{mM}$ Tris$\mathrm{HCl} \mathrm{pH} 8.1,2 \mathrm{mM}$ EDTA, $150 \mathrm{mM} \mathrm{NaCl}, 0.3 x$ protease inhibitor cocktail, $1 \%$ Triton$\mathrm{X} 100$, and $0.1 \%$ SDS) containing $0.50 \mathrm{mg}$ of suspended streptavidin-coated magnetic beads ( $\mathrm{C} 1$ beads) and then incubated at $4{ }^{\circ} \mathrm{C}$ for $20 \mathrm{~h}$ to pull down target DNA. Preparation of the beads was performed as follows: after removing the suspension solution from Dynabeads ${ }^{\circledR}$ MyOne ${ }^{\mathrm{TM}}$ Streptavidin $\mathrm{C} 1$, they were washed with modified COSMIC buffer and resuspended in it.

After the pull down, beads-bound DNA was isolated by reported affinity purification. ${ }^{4}$ Beads were washed once with $500 \mu \mathrm{L}$ of washing buffer 1 (10 mM Tris$\mathrm{HCl} \mathrm{pH}$ 8.0, $1 \mathrm{mM}$ EDTA, $0.3 \%$ SDS) for $7 \mathrm{~min}$, once with $500 \mu \mathrm{L}$ of washing buffer 2 (10 mM Tris- $\mathrm{HCl} \mathrm{pH}$ 8.0, $250 \mathrm{mM} \mathrm{LiCl}, 1 \mathrm{mM}$ EDTA, 0.5\% Nonidet P-40) for $5 \mathrm{~min}$, twice with $500 \mu \mathrm{L}$ washing buffer 3 (10 mM Tris- $\mathrm{HCl}$ pH 7.5, $1 \mathrm{mM}$ EDTA, $0.1 \%$ Nonidet P-40) for $5 \mathrm{~min}$ and twice with $500 \mu \mathrm{L}$ TE buffer $2(10 \mathrm{mM}$ Tris- $\mathrm{HCl} \mathrm{pH} 8.0$ and $1 \mathrm{mM}$ EDTA) for $5 \mathrm{~min}$. Beads were resuspended in elution buffer 1 (10 mM Tris- 
$\mathrm{HCl} \mathrm{pH}$ 7.6, $0.4 \mathrm{mM}$ EDTA and $100 \mathrm{mM} \mathrm{KOH}$ ) and DNA was eluted from magnetic beads after heating at $90{ }^{\circ} \mathrm{C}$ for $30 \mathrm{~min}$. The remaining DNA with the beads was eluted using elution buffer 2 (2\% SDS, $100 \mathrm{mM} \mathrm{NaHCO} 3$ and $3 \mathrm{mM}$ biotin) with the heating at $65^{\circ} \mathrm{C}$ for $8 \mathrm{~h}$. The detached DNA was purified with QIAquick PCR Purification Kit following the manufacture protocol and then quantified with a Nanodrop. Isolated DNA were pooled to get optimum DNA concentration for the sequencing library construction. Biological replicates were assessed.

High-throughput Sequencing. ${ }^{4 b}$ Sequencing libraries of the collected DNA were prepared with standard Ion Xpress ${ }^{\mathrm{TM}}$ Plus gDNA Fragment Library Preparation reagents (Thermo Fisher Scientific Inc.). A1 and P1 adapter-ligated enriched DNA was amplified and purified, followed by quality and quantity check with Agilent 2100 Bioanalyzer. The qualified libraries were used for high-throughput sequencing. Following the manufacture's protocol, the sequencing was performed, starting with template preparation using Ion $\mathrm{PI}^{\mathrm{TM}}$ template OT2 200 kit in Ion one touch 2 system (Thermo Fisher Scientific Inc.). The templates were then enriched using Ion one touch ES. The enriched libraries were sequenced with 300 flow of single read by Ion Proton ${ }^{\mathrm{TM}}$ Sequencer using Ion $\mathrm{PI}^{\mathrm{TM}}$ Sequencing 200 kit v3/ Ion PI chip by following the manufacturer's guidelines. 25-30 million post filtered reads per library were produced. The data were handled by employing standard program packages in the Ion torrent suit. Torrent Mapping Alignment Program 4.4.2 (TMAP) was used for aligning reads with the hg38 reference genome, and enriched peaks was called using MACS 1.4.2. ${ }^{5 \mathrm{a}}$ The enriched genomic regions were visualized using UCSC genome browser (http://genome.ucsc.edu/). Homer motif analysis program was used for the de novo motif analysis. ${ }^{5 b}$ 

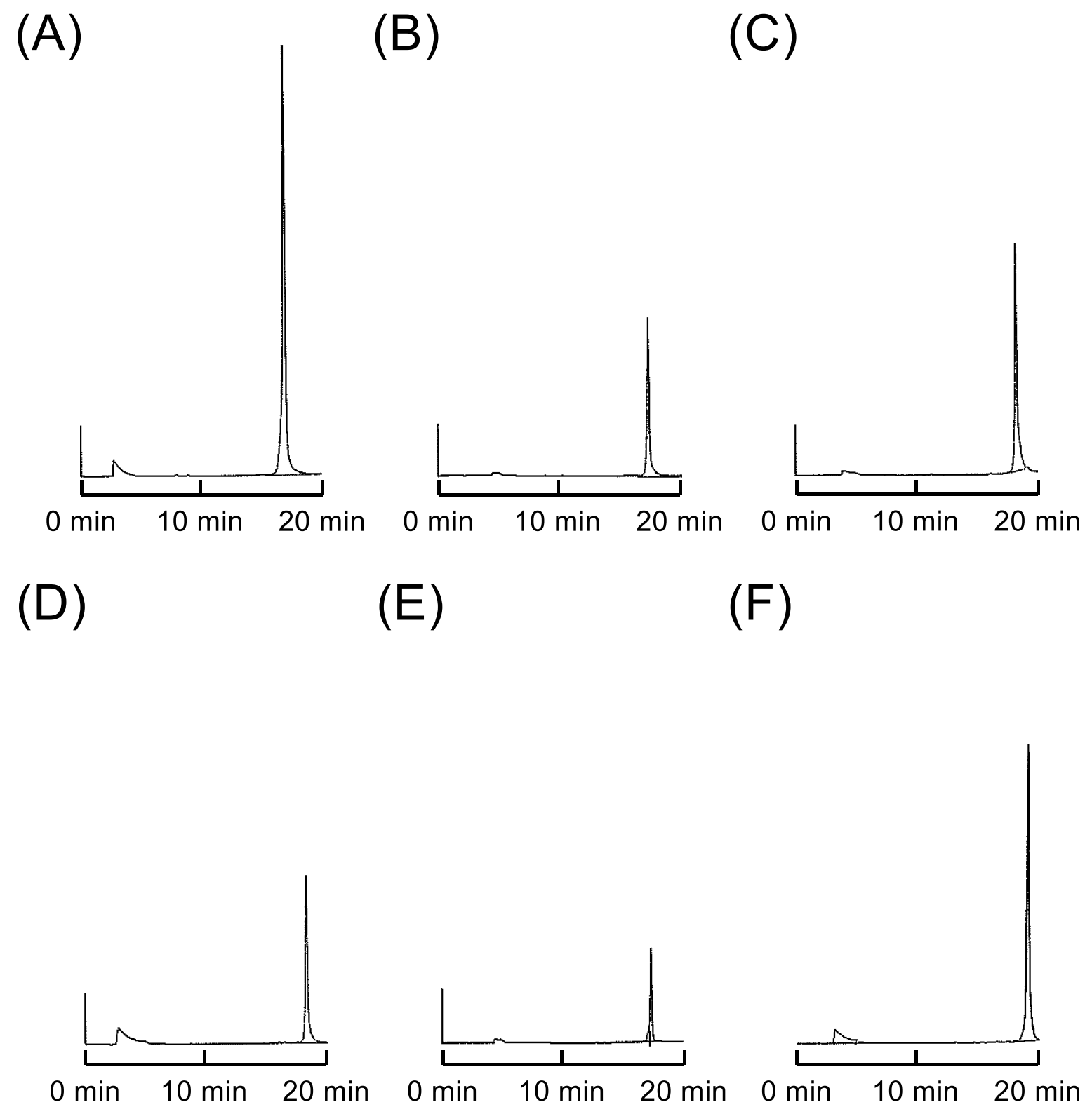

Figure S1. Analytical HPLC profiles of Py-Im polyamides (A: TTet59-A, B: TTet59 B, C: TAMRA TTet59-A, D: TAMRA TTet59-B, E: Biotin TDi59-A, F: Biotin TTet59-B). 
(A)

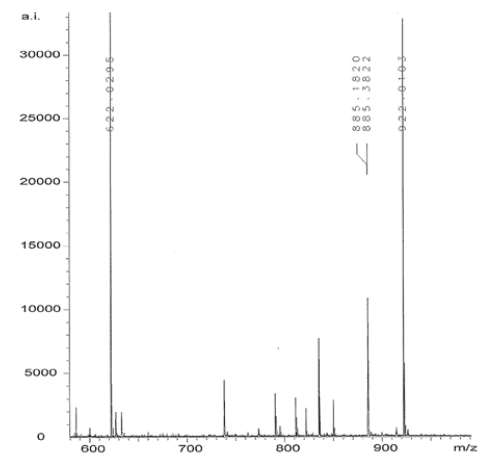

(D)

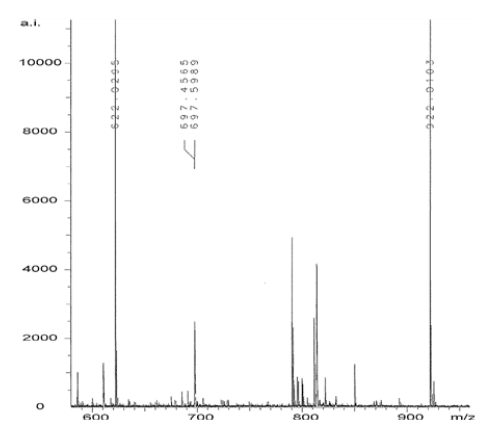

(B)

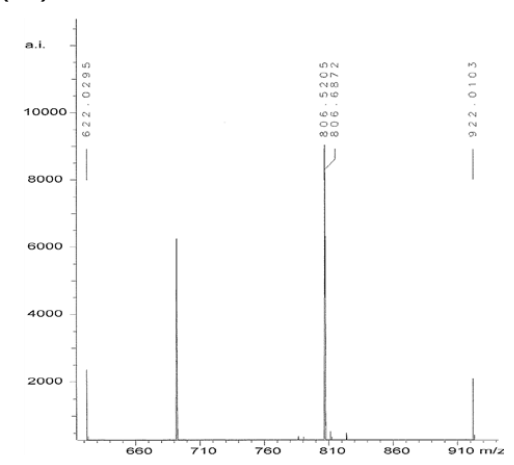

(E)

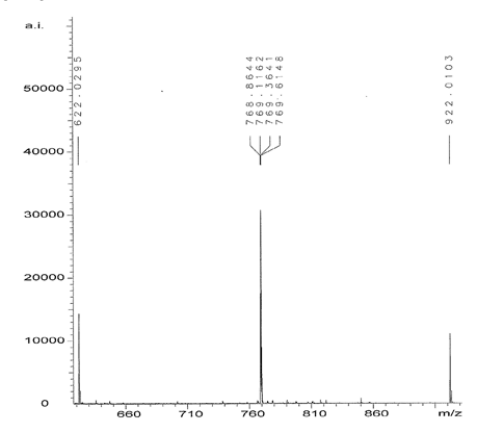

(C)

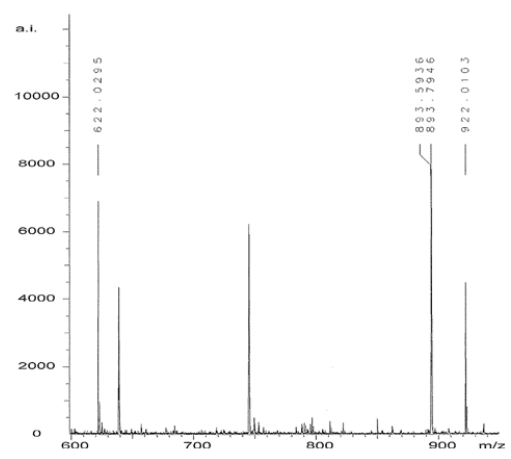

$(\mathrm{F})$

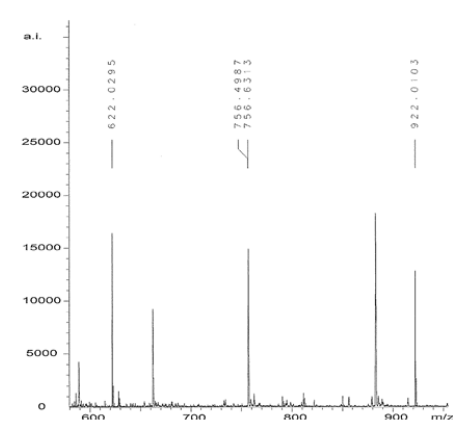

Figure S2. ESI-TOF MS spectra of Py-Im polyamides (A: TTet59-A, B: TTet59-B, C: TAMRA TTet59-A, D: TAMRA TTet59-B, E: Biotin TDi59-A, F: Biotin TTet59-B). 
(A)

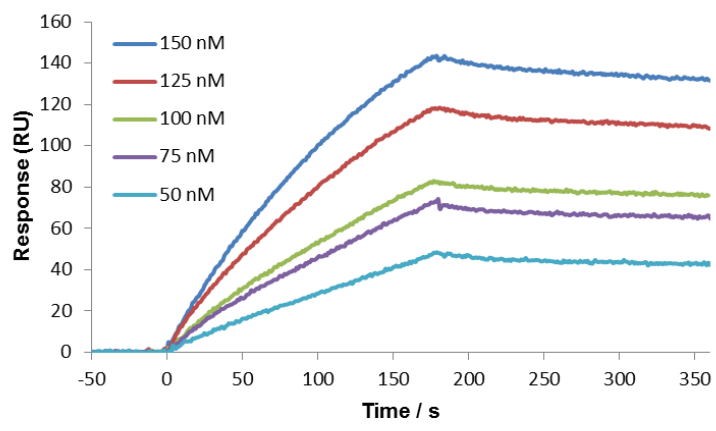

(C)

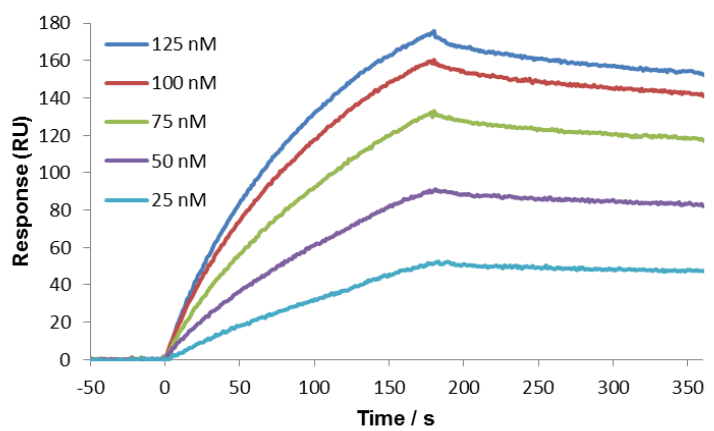

(B)

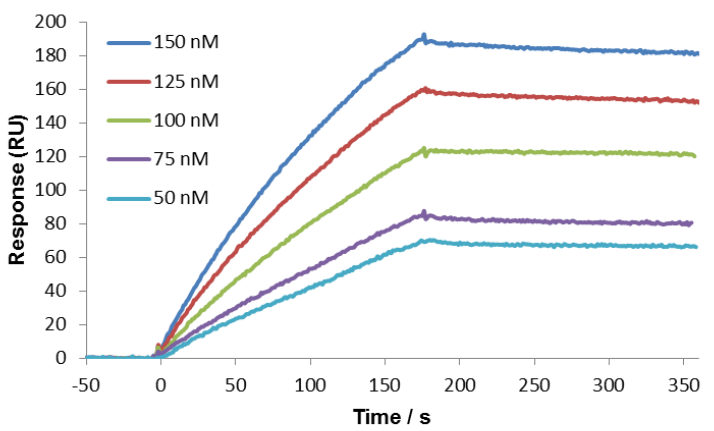

ODN1: 5 '-Biotin-GGTTAGGGTTAGGGTTAGGGTTAGGGTTAGG

Figure S3. SPR sensorgrmas for the interaction between ODN-1 and (A) TTet59-A, (B) TTet59-B or (C) TTri59-A. 
A

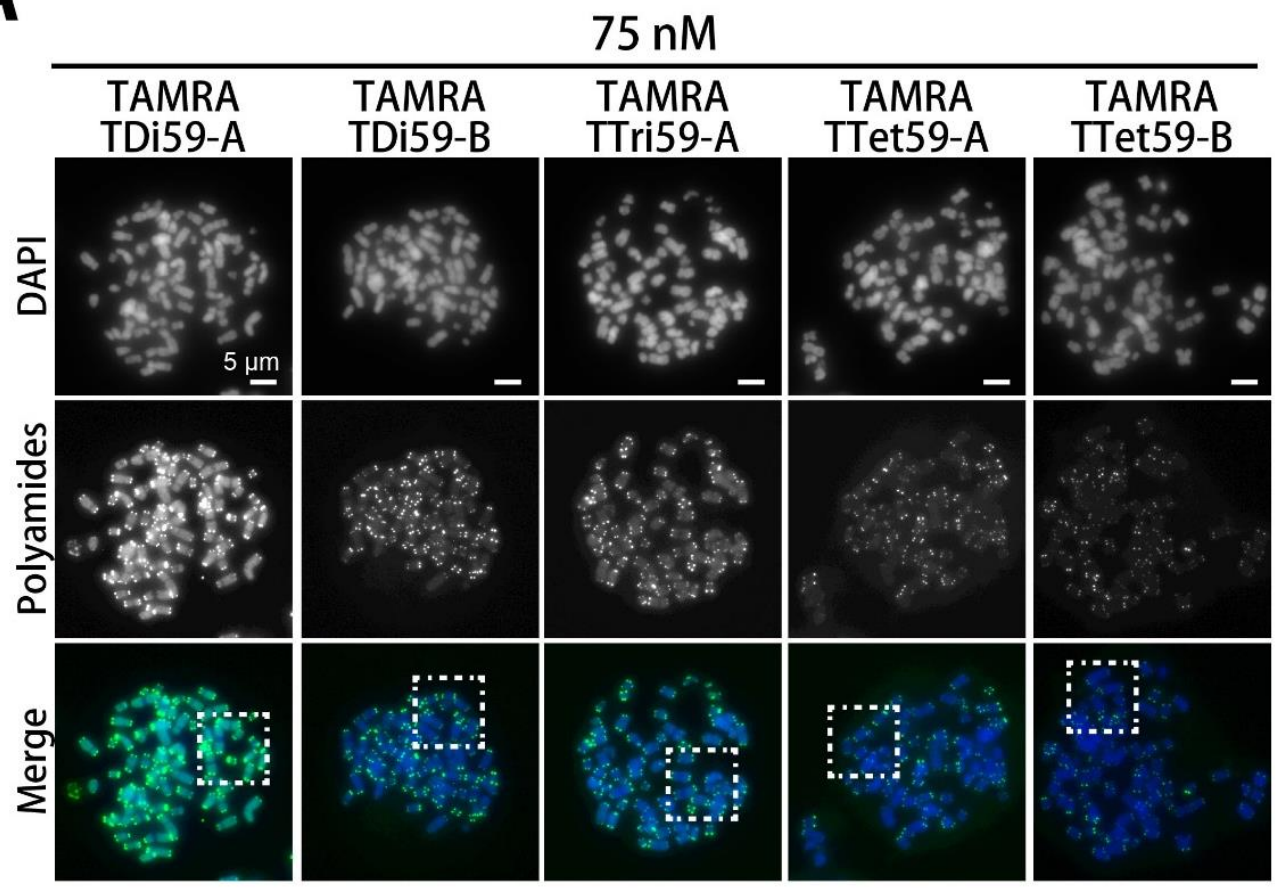

B

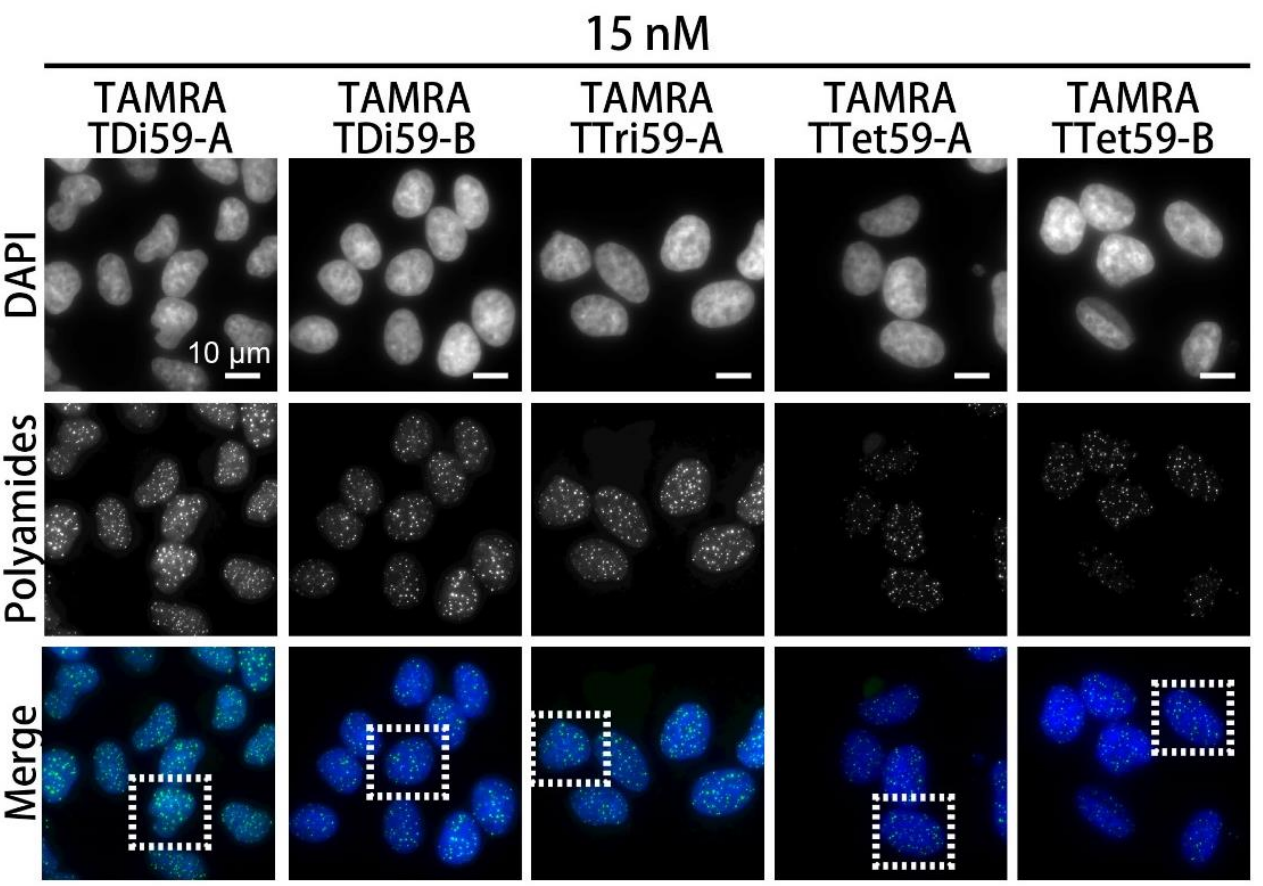

Figure S4. Full images of HeLa 1.3 cell spreads in Figure 2 and HeLa 1.3 cells in Figure 3. Enlarged images of the boxed regions in (A) and (B) are shown in Figure 2 and 3 , respectively. 


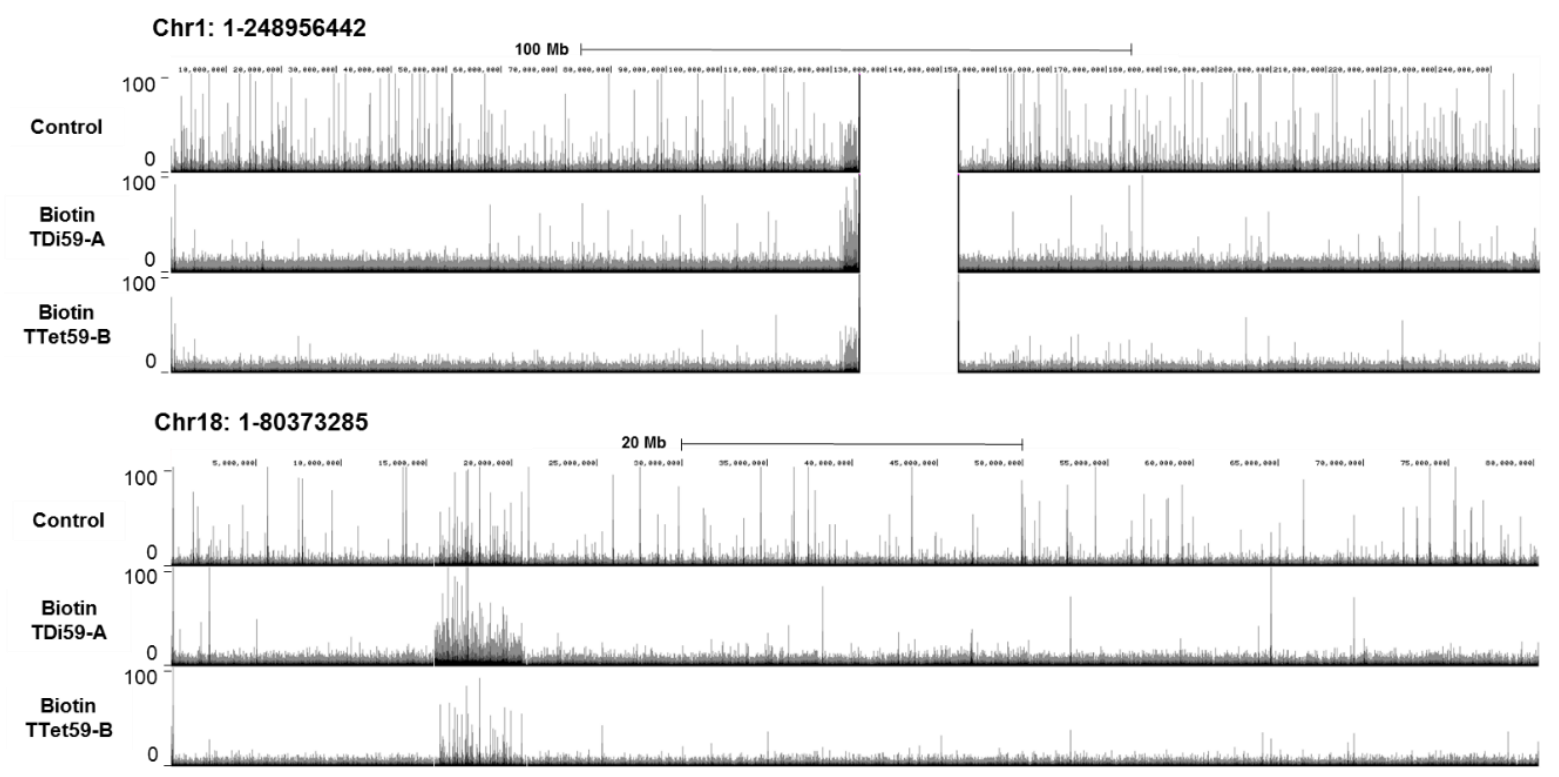

Figure S5. Mapping of the biotinylated Py-Im polyamide probes binding and enriched sites in the whole of chromosomes 1 and 18. 

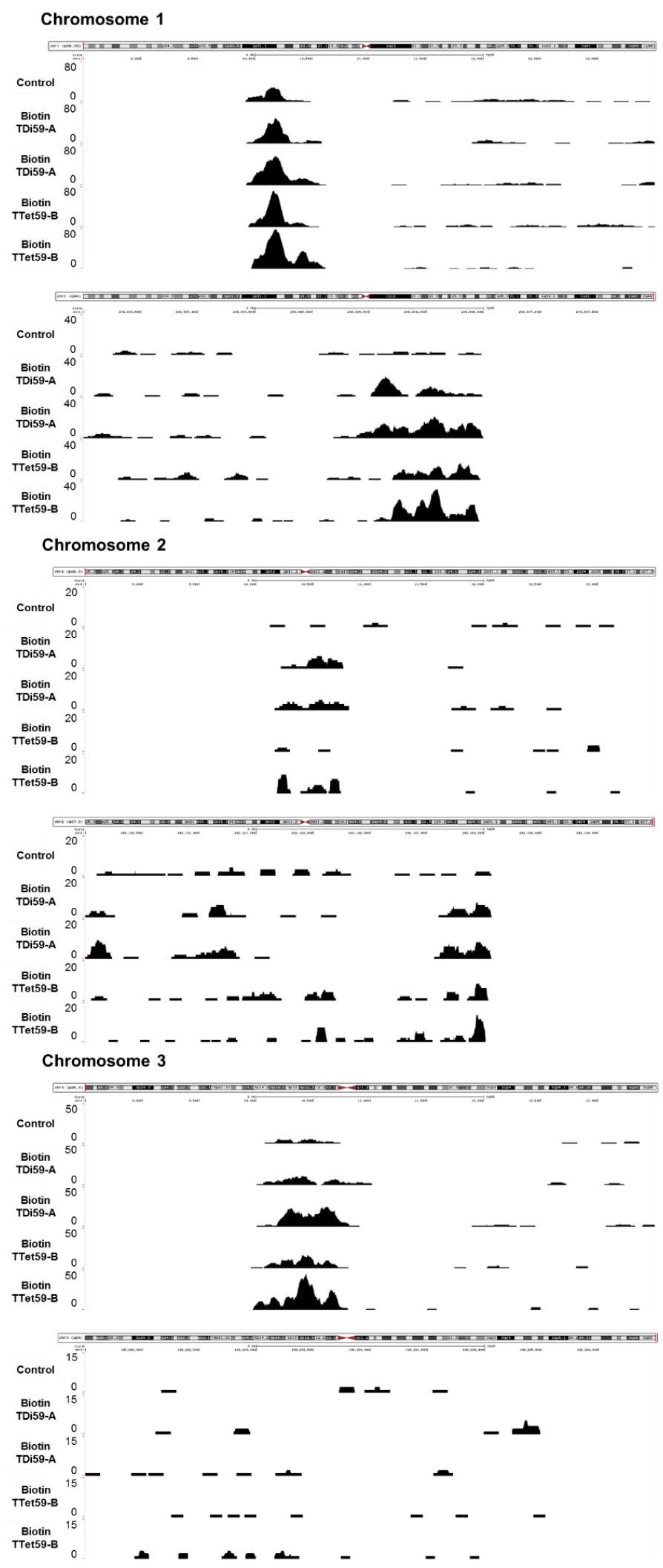

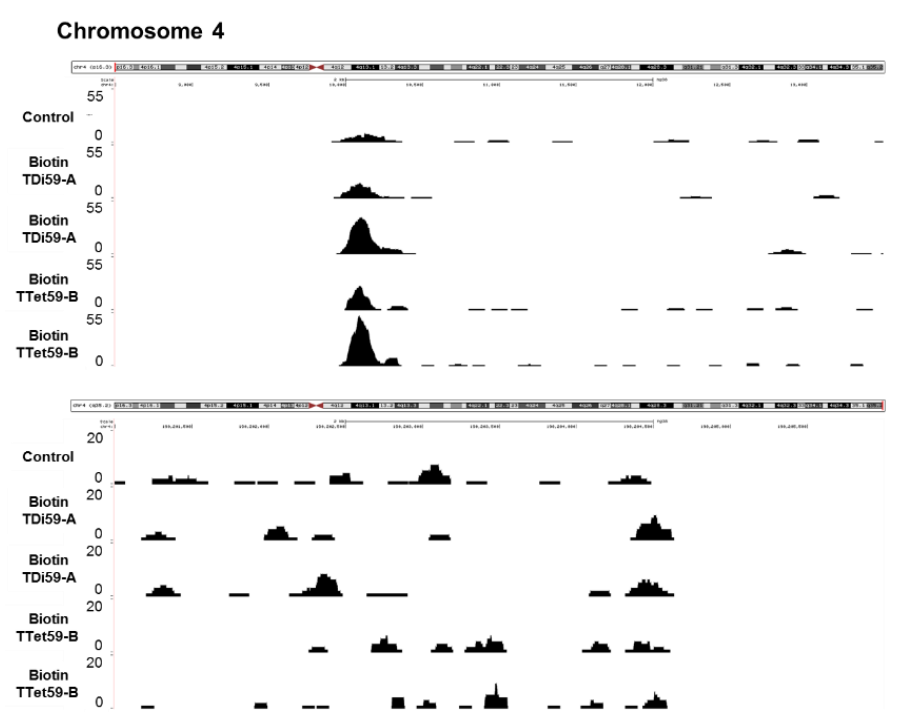

Chromosome 5

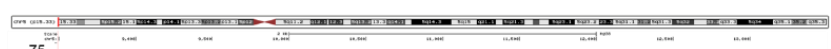
\begin{tabular}{|cc|}
\hline Control & 0 \\
\hline Biotin & 75 \\
Tois9-A & 0 \\
\hline Biotin & 75 \\
Tois9-A & 0 \\
\hline Biotin & 75 \\
\hline TTet59-B & 0 \\
\hline Biotin & 75 \\
\hline Teet59-B & 0 \\
\hline
\end{tabular}

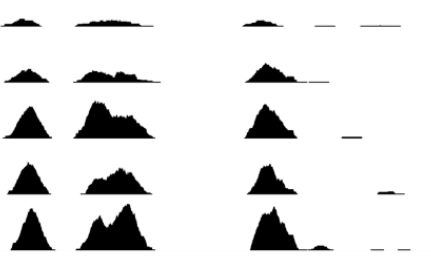

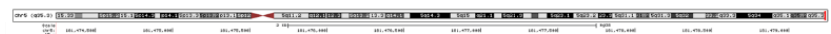

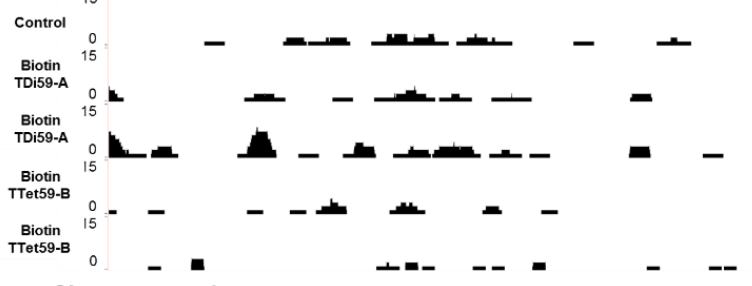

Chromosome 6
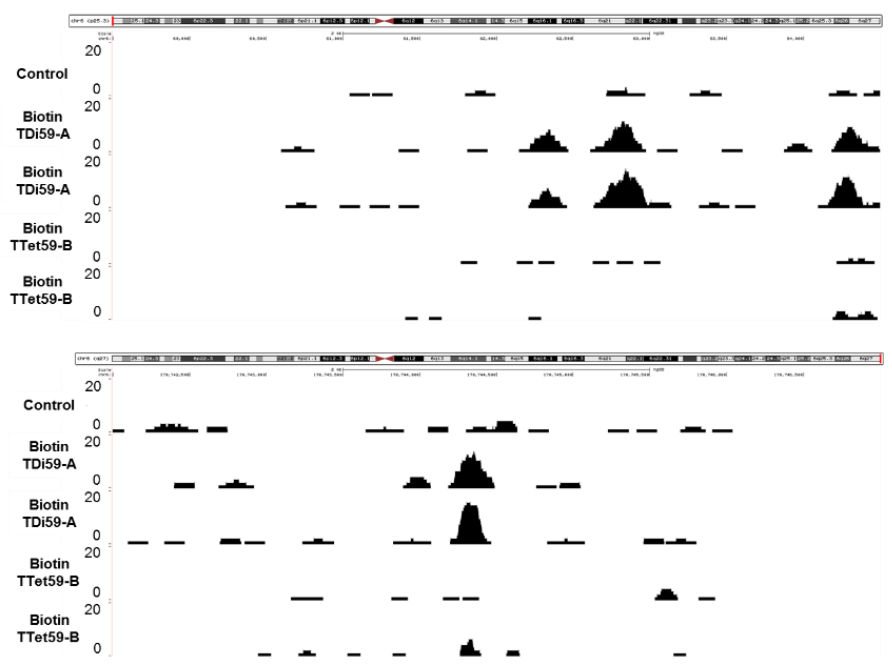

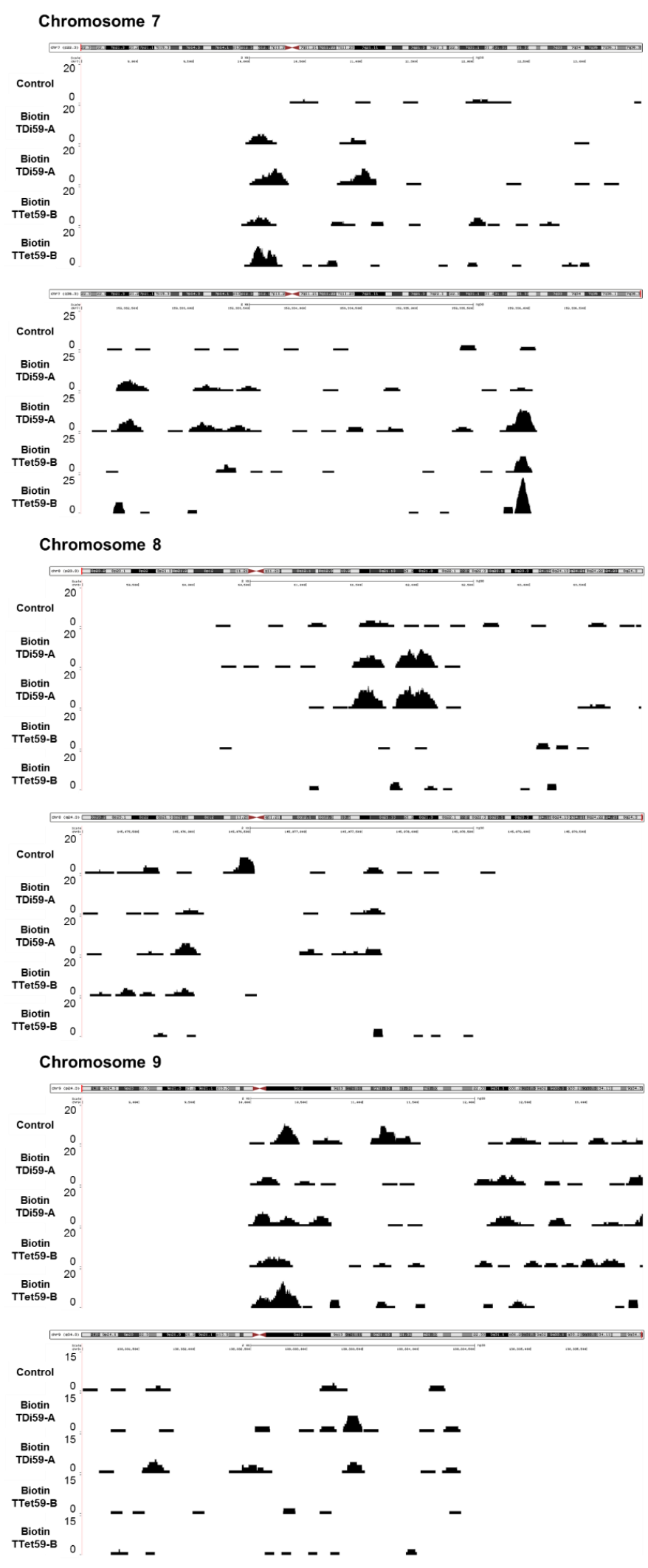

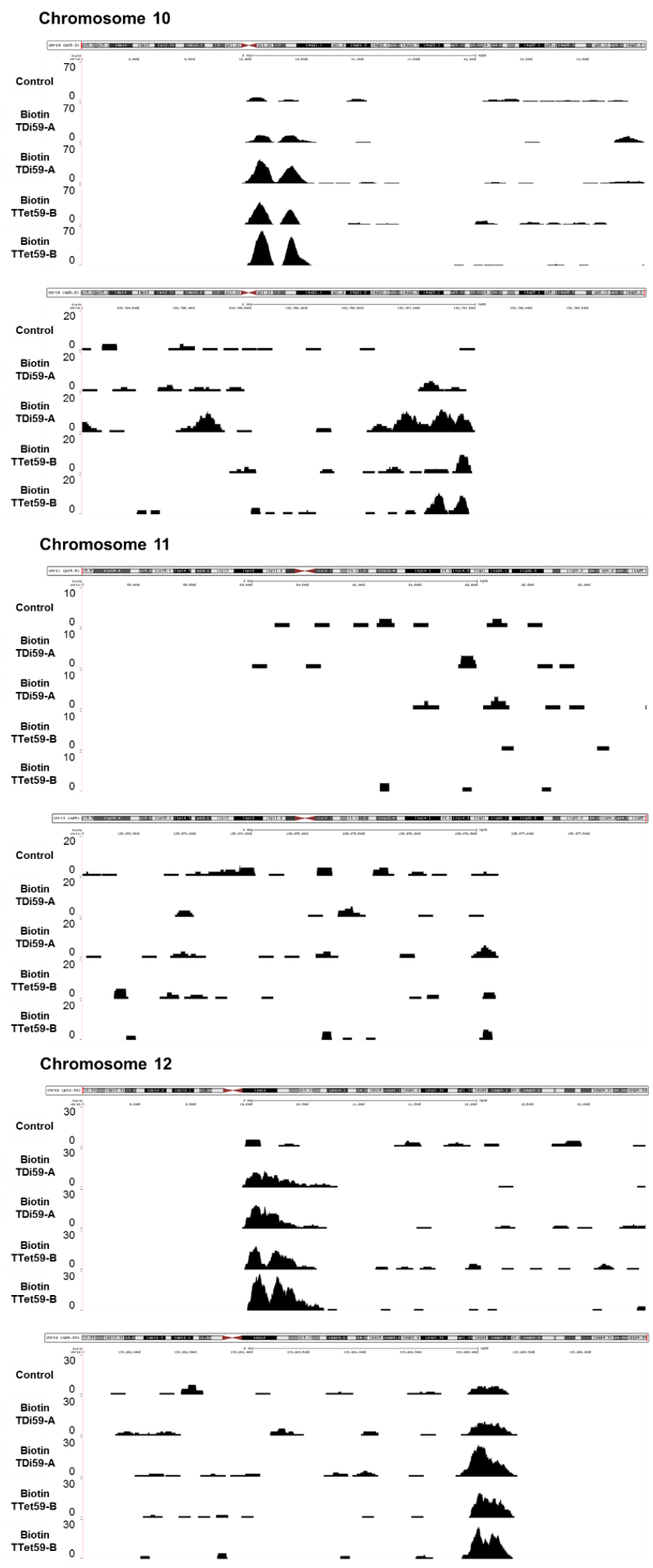

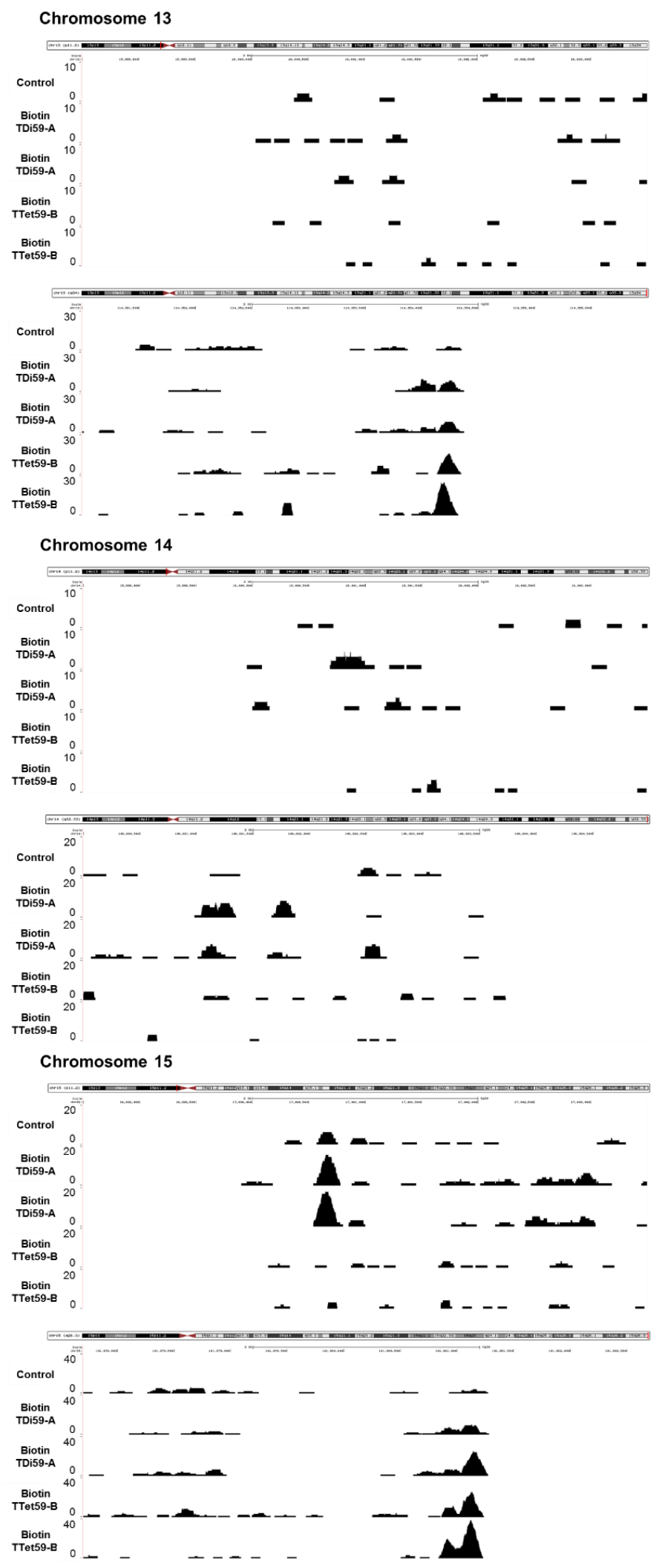

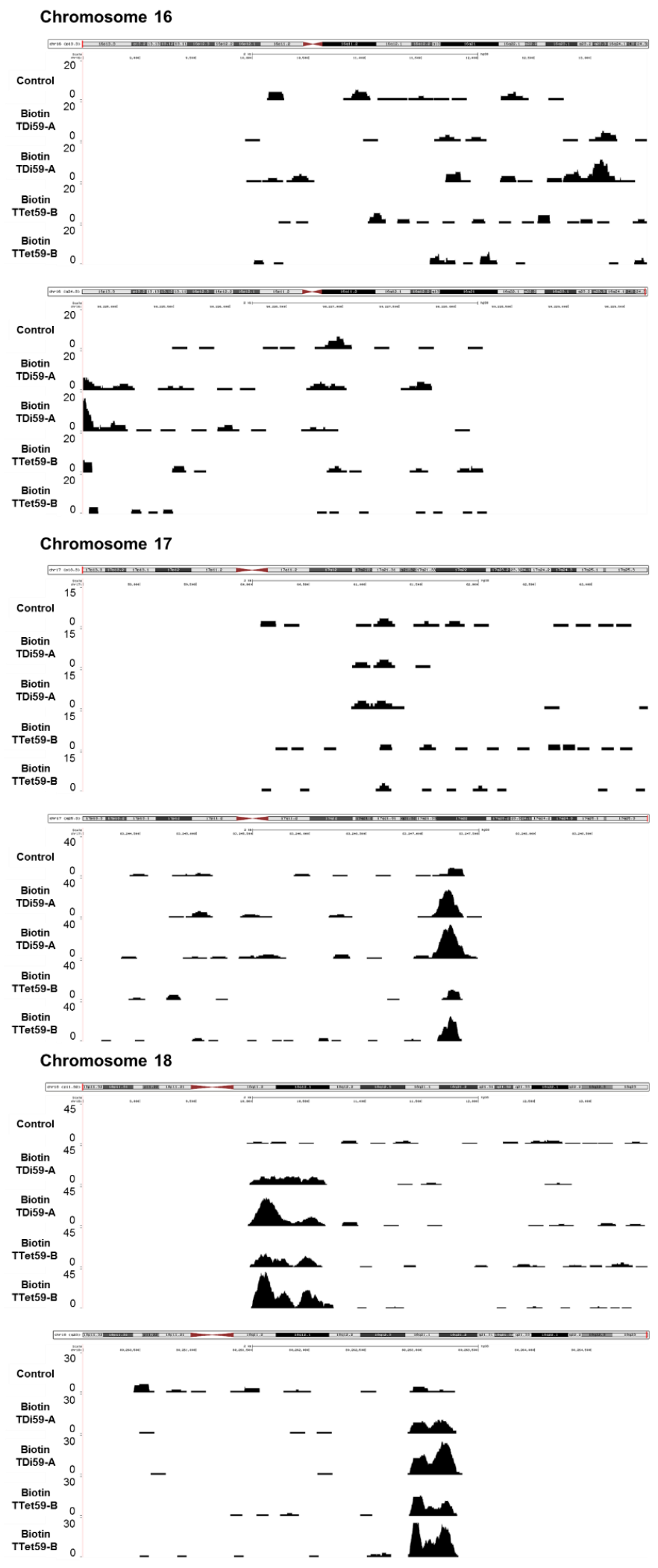

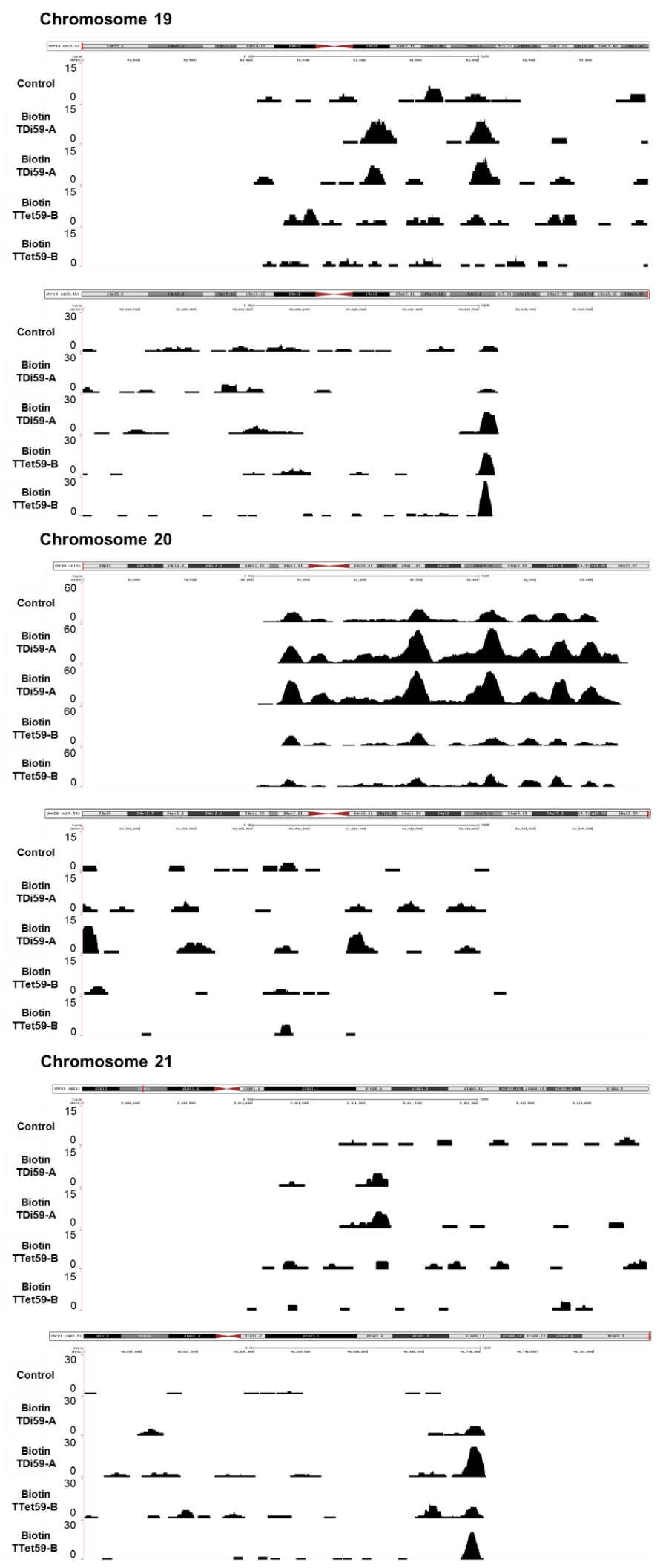

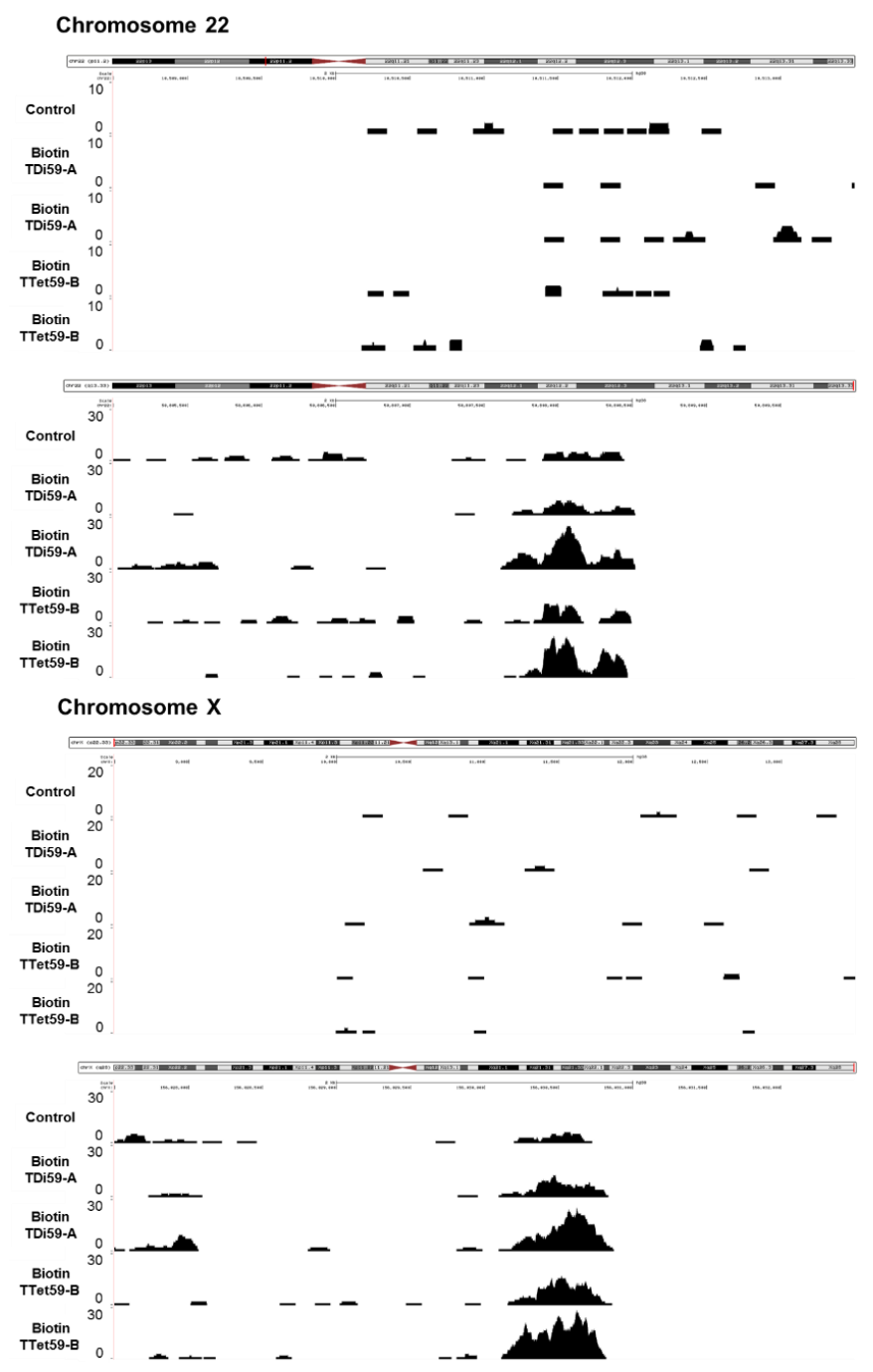

Figure S6. The enrichment of Biotin TDi59-A and Biotin TTet59-B at both termini for all chromosomes. 


\section{References}

(1) (a) Kawamoto, Y.; Bando, T.; Kamada, F.; Li, Y.; Hashiya, K.; Maeshima, K.;

Sugiyama, H. J. Am. Chem. Soc. 2013, 135, 16468-16477. (b) Hirata, A.; Nokihara, K.;

Kawamoto, Y.; Bando, T.; Sasaki, A.; Ide, S.; Maeshima, K.; Kasama, T.; Sugiyama, H. J. Am. Chem. Soc. 2014, 136, 11546-11554. (c) Kawamoto, Y.; Sasaki, A.; Hashiya, K.; Ide, S; Bando, T.; Maeshima, K; Sugiyama. H. Chem. Sci. 2015, 6, 2307-2312. (d) Sasaki, A.; Ide, S.; Kawamoto, Y.; Bando, T.; Murata, Y.; Shimura, M.; Yamada, K.; Hirata, A.; Nokihara, K.; Hirata, T.; Sugiyama, H.; Maeshima, K. Sci. Rep. 2016, 6, 29261. (e) Maeshima, K.; Janssen, S.; Laemmli, U. K. EMBO J. 2001, 20, 3218-3228. (2) Minoshima, M.; Bando, T.; Sasaki, S.; Fujimoto, J.; Sugiyama, H. Nucleic Acids Res. 2008, 36, 2889-2894.

(3) (a) Maeshima, K.; Laemmli, U. K. Dev. Cell 2003, 4, 467-480. (b) Maeshima, K.; Yahata, K.; Sasaki, Y.; Nakatomi, R.; Tachibana, T.; Hashikawa, T.; Imamoto, F.; Imamoto, N. J. Cell Sci. 2006, 119, 4442-4451.

(4) (a) Erwin, G. S.; Bhimsaria, D.; Eguchi, A.; Ansari, A. Z. Angew. Chem. Int. Ed. 2014, 53, 10124-10128. (b) Chandran, A.; Syed, J.; Taylor, R. D.; Kashiwazaki, G.; Sato, S.; Hashiya, K.; Bando, T.; Sugiyama, H. Nucleic Acids Res. 2016, 44, 4014-4024. (c) Chandran, A.; Syed, J.; Li, Y.; Sato, S.; Bando, T.; Sugiyama, H. ChemBioChem. 2016, DOI: $10.1002 /$ cbic. 201600274.

(5) (a) Feng, J.; Liu, T.; Qin, B.; Zhang, Y.; Liu, X. S. Nat. Protoc. 2012, 7, 1728-1740.

(b) Heinz, S.; Benner, C.; Spann, N.; Bertolino, E.; Lin, Y. C.; Laslo, P.; Cheng, J. X.; Murre, C.; Singh, H.; Glass, C. K. Mol. Cell 2010, 38, 576-589. 